Atmos. Chem. Phys. Discuss., https://doi.org/10.5194/acp-2017-1192

\title{
The underestimated role of stratosphere-to-troposphere transport on tropospheric ozone
}

\author{
Thomas Trickl ${ }^{1}$, Hannes Vogelmann ${ }^{1}$, Ludwig Ries ${ }^{2}$, Hans-Eckhart Scheel ${ }^{1,+}$ and Michael Sprenger ${ }^{3}$ \\ ${ }^{1}$ Karlsruher Institut für Technologie, Institut für Meteorologie und Klimaforschung, IMK-IFU, Kreuzeckbahnstr. \\ 5 19, 82467 Garmisch-Partenkirchen, Germany \\ ${ }^{2}$ Umweltbundesamt II 4.5, Plattform Zugspitze, GAW-Globalobservatorium Zugspitze-Hohenpeißenberg, Schnee- \\ fernerhaus, 82475 Zugspitze, Germany \\ ${ }^{3}$ Eidgenössische Technische Hochschule (ETH) Zürich, Institut für Atmosphäre und Klima, Universitätstraße 16, \\ 8092 Zürich, Switzerland \\ ${ }^{+}$Deceased on June 23, 2013
}

Correspondence to: Dr. Thomas Trickl, thomas.trickl@kit.edu, Tel. +49-8821-183-209, Fax +49-8821-73573

Abstract. The atmospheric composition is strongly influenced by changing atmospheric dynamics, in potential relation to climate change. A prominent example is the doubling of the stratospheric ozone component at the summit station Zugspitze (2962 m a.s.1., Garmisch-Partenkirchen, Germany) between the mid-seventies and 2005 , roughly from $11 \mathrm{ppb}$ to $23 \mathrm{ppb}$ (43\%). Systematic efforts for identifying and quantifying this influence have been made since the late 1990s. Meanwhile, routine lidar measurements of ozone and water vapour carried out since 2007, combined with in-situ and radiosonde data and trajectory calculations, have revealed the presence of stratospheric intrusion layers on $84 \%$ of the yearly measurement days. The seasonal cycle for deep intrusions with a pronounced summer minimum seen at Alpine summit stations disappears if one looks at the entire free troposphere. The seasonal cycle previously obtained for the Zugspitze summit is rather well reproduced by the lidar data. The mid- and upper-tropospheric intrusion layers seem to be dominated by very long downward transport up to a full tour around the northern hemisphere in an altitude range starting at about $4.5 \mathrm{~km}$ a.s.l. Unless there is a strong perturbation, these layers remain considerably dry, typically with $\mathrm{RH} \leq 5 \%$ at the centre of the intrusion. It is interesting to note that, in recent years, most pronounced ozone maxima have been related to a stratospheric origin rather than to long-range transport from remote boundary layers. This fact could be caused by improving air quality in the most relevant source regions or changing transport patterns.

Key words: Ozone, water vapour, aerosol, stratosphere-to-troposphere transport, transport modelling, lidar, LAGRANTO

\section{Introduction}

Quantifying stratosphere-to-troposphere transport (STT) has been attempted as long as over more than half a century. After early studies to identify the general mechanisms (e.g., Danielsen, 1968) more recent work has also estimated of the STT budget by extrapolations of observational data (e.g,, Danielsen and Mohnen, 1977; Viezee et al., 1983; Beekmann et al., 1997), and by modelling efforts (e.g., Roelofs and Lelieveld, 1997; Kentarchos and 35 Roelofs, 2003; Stevenson et al., 2006; Wild, 2007; Young et al., 2013). There is, still, a considerable uncertainty of the results. The global distribution is rather inhomogeneous with maxima in regions around the jet-stream belts (James et al., 2003; Sprenger et al., 2003; Škerlak et al., 2014)). Sprenger et al. (2003) found that the role of 
the subtropical jet stream (STJ) for STT had been strongly underestimated. The STJ persists during most of the year, but it is not only the persistence that matters: Very strong ozone signatures in the troposphere exceeding 200 ppb have been detected over northern India (Ojha et al., 2014; 2017). High ozone values in the middle and upper troposphere from regions next to the STJ have even been observed above Garmisch-Partenkirchen (Germany) after transport almost all the way around the northern hemisphere (Trickl et al., 2011).

An approach to quantify the fraction of stratospheric ozone based on observations alone was made by Scheel (pp. 66-71 in (ATMOFAST, 2005)) for the lower-tropospheric site Zugspitze (2962 m a.s.1.) in the German Alps. Here, ozone rose from 1978 to about 2003, in contrast to the neighbouring Wank site (1780 m a.s.1.) where constant ozone was observed since the 1980s. Elbern et al. (1997) found that the higher Zugspitze station registered more than twice the stratospheric air intrusions than the lower Wank site which is in agreement with the trend difference. Scheel also detected that the only significantly growing ozone component in the 1990s was associated with very dry air that had obviously descended from high altitudes (Scheel, 2003). By correlating ozone with ${ }^{7} \mathrm{Be}$ and low relative humidity (RH) STT events can be clearly identified (“direct intrusions”). A positive trend of the direct stratospheric component in Zugspitze ozone was found even back to the beginning of the high-quality measurements at the Zugspitze summit in 1978, the contribution, however, being below $10 \%$ (Fig. 1). The indirect component that cannot be identified by data filtering was estimated from ${ }^{7} \mathrm{Be}$ considering that $2 / 3$ of ${ }^{7} \mathrm{Be}$ had been reported to be of stratospheric origin (Lal and Peters, 1967). ${ }^{7} \mathrm{Be}$ was converted to ozone by calibration with the direct component. Both stratospheric components in Fig. 1 grew from 1978 to 2003, the clearest evidence of an increasing STT contribution coming from ${ }^{7} \mathrm{Be}$ that started to rise in the mid-seventies. In 2003, the stratospheric ozone component reached an astonishing value of $23.4 \mathrm{ppb}$ (i.e., $43.4 \%$ of the 2003 annual average). This result seems to confirm the average $40 \%$ obtained by Roelofs and Lelieveld (1997) for the entire troposphere. ${ }^{7} \mathrm{Be}$ has been measured at the Zugspitze summit since late 1969 (Reiter et al., 1971). This series reveals that the positive trend started in the mid-seventies. A comparable positive ozone trend is also reported for the Swiss Jungfraujoch station (3580 m a.s.l.) where the measurements started in 1992 (Ordoñez et al., 2007). For the lower-lying Italian station Monte Cimone (2165 m a.s.l.) the absence of a significant correlation between ozone and the intrusion frequency was concluded, but for the years 1996 to 2011, that are rather late compared with the main rise at the Alpine sites (Cristofanelli et al., 2015).

Scheel's approach is still associated with an uncertainty of unknown magnitude, in part because of the limited decay time of this isotope (53.42 $( \pm 0.01)$ days; Huh and Liu, 2000). However, the result cannot be too wrong since the 1978 stratospheric fraction of $11.3 \mathrm{ppb}(31.2 \%)$ is in the range of expectations from the Montsouris value derived from measurement in the late $19^{\text {th }}$ century (Volz and Kley, 1988). In addition, after subtracting the stratospheric contribution the positive trend disappears. From the decline of the ozone precursors in the 1990s (e.g., Jonson et al., 2006; Vautard et al., 2006) one would have even expected a negative development. Thus, the result is perhaps even somewhat conservative.

35 The most reasonable explanation in our view has been a reaction of the atmospheric dynamics to the climate change. Indeed, several authors have given hints on this (e.g., Collins et al., 2003; Lin et al., 2015; Neu et al., 2014).

Trickl et al. (2010) analysed the data-filtering criteria for STT events reaching the Zugspitze summit. By comparison with transport model predictions and backward trajectories they found that the criteria used (also in Fig. 1) are highly reliably for identifying stratospheric air masses. However, the ${ }^{7} \mathrm{Be}$ thresholds previously used 
Atmos. Chem. Phys. Discuss., https://doi.org/10.5194/acp-2017-1192

were found to be far too high. Thus, it is planned to revise the calculations and to look for a potential positive trend of the annual intrusion count. In view of a full quantification one open question had been the influence of tropospheric mixing of the descending air layers. Lidar measurements revealed that mixing is rather small and in many cases almost negligible (Trickl et al., 2014; 2015; 2016).

The seasonal cycle of ozone at Alpine summit stations exhibits a pronounced summer minimum (Elbern et al, 1997; Stohl et al., 2000; Trickl et al., 2010). By contrast, Beekmann et al. (1997) concluded for the entire free troposphere above three European ozone-sonde stations a seasonal cycle with a slight summer maximum, based on data filtering of ozone profiles between 1969 and 1994. A transition to this behaviour is indicated for growing altitude of the Alpine stations: The summer minimum is least pronounced at the highest of the stations previously compared, Jungfraujoch (see Fig. 1 of Trickl et al., 2010).

In this paper, we extend our STT studies to the full free troposphere. The analysis is based on routine lidar measurements of ozone, water vapour and aerosol since 2007, as well as radiosonde relative humidity and transport modelling. These results reveal a surprisingly strong stratospheric component in tropospheric ozone over Central Europe.

\section{Methods}

\subsection{Measurements}

\subsubsection{IFU ozone DIAL}

The tropospheric ozone lidar is operated in Garmisch-Partenkirchen, Germany at IMK-IFU (formerly IFU; $47^{\circ}$ $28^{\prime} 37^{\prime \prime} \mathrm{N}, 11^{\circ} 3^{\prime} 52^{\prime \prime} \mathrm{E}, 740 \mathrm{~m}$ a.s.l.). The laser source is a Raman-shifted $\mathrm{KrF}$ laser, and two separate receiving telescopes are used to divide the dynamic range of the backscatter signal of roughly eight decades. This lidar was completed as a two-wavelength differential-absorption lidar (DIAL) in 1990 (Kempfer et al., 1994) and a first annual sounding series was achieved in 1991 (Carnuth et al., 2002). It was upgraded to a three-wavelength DIAL in 1994 and 1995 (Eisele and Trickl, 1997), leading to a unique vertical range between roughly $0.25 \mathrm{~km}$ above the ground and 3 to $5 \mathrm{~km}$ above the tropopause, the measurement time interval being just $41 \mathrm{~s}$. By comparing the ozone profiles retrieved from different wavelength combinations (e.g., $277 \mathrm{~nm}-313 \mathrm{~nm}$ or $292 \mathrm{~nm}-313 \mathrm{~nm}$ an internal quality check is possible. The choice of an "on" wavelength below $280 \mathrm{~nm}$ is particularly beneficial for achieving a high accuracy and a high vertical resolution (up to about $5 \mathrm{~km}$ above the ground). Density has been converted to mixing ratio by using pressure and temperature data from nearby radiosonde stations (Sect. 2.1.4). The DIAL features low uncertainties of about $\pm 3 \mathrm{ppb}$ in the lower free troposphere, approximately doubling (under optimum conditions) in the upper troposphere. Comparisons with the nearby Zugspitze in-situ measurements (at $2962 \mathrm{~m}$ a.s.l., see below) show no relevant mutual bias, the standard deviation of the differences being less than $2 \mathrm{ppb}$. The uncertainty further diminished after another system upgrading in 2012, after introducing a new ground-free input stage to our transient digitizers (Licel) that reduced the noise level by roughly a factor of three. For the range covered by the near-field receiver (below $1.2 \mathrm{~km}$ above the lidar) the uncertainty is of the order of $\pm 5 \mathrm{ppb}$. The upper-tropospheric performance may be degraded in the presence of high lower-tropospheric ozone concentrations absorbing a lot of the ultraviolet laser emission and by enhanced sky light in summer, in particular in the presence of clouds. Thus, longer data acquisition times, requiring some technical modifications, are planned for the future. The vertical resolution is dynamically varied between $50 \mathrm{~m}$ 
and a few hundred metres, depending on the signal-to-noise ratio decreasing with altitude. Within stratospheric intrusion layers the vertical resolution is reduced as far as possible in order to avoid a reduction of the peak concentrations by smoothing. The lidar has been used in numerous atmospheric transport studies (e.g., Eisele et al., 1999; Stohl and Trickl, 1999; Trickl et al., 2003; and other publications cited in this paper).

Aerosol backscatter profiles with very good signal-to-noise ratio up to the lower stratosphere are obtained from the 313-nm "off" channel of the lidar. The methods, implying an ozone correction, have been described by Eisele and Trickl (2005). Examples demonstrating the data quality achieved in recent years (maximum noise level of the backscatter coefficients: $\pm 1 \times 10^{-7} \mathrm{~m}^{-1} \mathrm{sr}^{-1}$, reached in the tropopause region) can be seen in (Trickl et al., 2015). We derive vertical profiles of the aerosol backscatter coefficients based on on a constant

10 backscatter-to-extinction ratio of $0.020 \mathrm{sr}^{-1}$, which is the average value derived within the European Aerosol Research Lidar Network (EARLINET, 2003). Within clouds larger values are taken, if possible optimized for minimum discrepancy of the backscatter profiles below and above the cloud.

\subsubsection{IFU water-vapour DIAL at the Schneefernerhaus high-altitude station}

The Zugspitze water-vapour DIAL is operated at the Schneefernerhaus high-altitude research station (UFS, $47^{\circ}$

$25^{\prime} 00^{\prime \prime} \mathrm{N}, 10^{\circ} 58^{\prime} 46^{\prime \prime} \mathrm{E}$ ) at $2675 \mathrm{~m}$ a.s.1., about $8.5 \mathrm{~km}$ to the south-west of IMK-IFU (Garmisch-Partenkirchen, Germany), and $0.5 \mathrm{~km}$ to the south-west of the Zugspitze summit. The full details of this lidar system were described by Vogelmann and Trickl (2008). It is based on a powerful tunable narrow-band Ti:sapphire laser system with up to $250 \mathrm{~mJ}$ energy per pulse operated at about $817 \mathrm{~nm}$ and a $0.65-\mathrm{m}$-diameter Newtonian receiver. Due to these specifications a vertical range up to about $12 \mathrm{~km}$ can be reached, almost unaffected by daylight. However, mostly the laser has been operated at half the maximum pulse energy or less to extend the life time of the high-voltage components such as flashlamps. A separation of near-field and far-field signals is achieved by a combination of a beam splitter and a blade in the far-field channel. The operating range starts below the altitude of the summit station (2962 m a.s.1.). The electronics are almost identical to those of the ozone DIAL. However, at the operating wavelength of $817 \mathrm{~nm}$ avalanche photodiodes have been used that introduce higher noise than the photomultiplier tubes preferred for shorter wavelengths. Thus, the system has not yet reached its expected optimum performance in the upper troposphere.

The vertical resolution chosen in the data evaluation is dynamically varied between $50 \mathrm{~m}$ in altitude regions with good signal-to-noise ratio and roughly $350 \mathrm{~m}$ in the upper troposphere. Free-tropospheric measurements during dry conditions clearly benefit from the elevated site outside or just below the edge of the moist Alpine boundary layer (e.g., Carnuth and Trickl, 2000; Nyeki et al., 2000; Carnuth et al., 2002). After a few years of testing, validating and optimizing the system routine measurements were started in January 2007 with typically two measurement days per week, provided that the weather conditions are favourable. Operation has been interrupted since Winter 2015 due to fatal laser damage. A new Ti:sapphire laser system is under development.

The lidar has been validated in several comparisons with local and remote radiosonde ascents (Vogelmann and 35 Trickl, 2008), an airborne DIAL (Trickl et al., 2016) and the Zugspitze Fourier-transform spectrometer (Vogelmann et al. 2011). A noise level of $5 \%$ and a bias of $1 \%$ at most was verified to more than $6 \mathrm{~km}$. Furthermore, a very high importance of volume matching in comparisons of water-vapour profiling instruments was found (see also (Vogelmann et al, 2011; 2015), on the scale of a quarter of an hour and a few kilometres. 
Atmos. Chem. Phys. Discuss., https://doi.org/10.5194/acp-2017-1192

In some cases in which a direct comparison of the exact matching of the humidity and aerosol layers was necessary (e.g., Trickl et al., 2016) aerosol backscatter coefficients were retrieved from the "off" wavelength channel. The calculations were done with a program developed for the IFU aerosol lidar systems (e.g., Trickl et al., 2013; Wandinger et al., 2016).

\subsubsection{In-situ measurements at the Zugspitze summit and at the Schneefernerhaus station (UFS)}

In addition, in-situ data from the monitoring station at the Zugspitze summit (air inlet: $2962 \mathrm{~m}$ a.s.1.) have been inspected, namely ozone and relative humidity. Ozone was measured between 1978 and 2012 (e.g., Reiter et al., 1987; Scheel et al., 1997; Oltmans et al., 2006; 2012; Logan et al., 2012; Parrish et al., 2012). At present the data have been evaluated until 2010. The relative uncertainty of the Zugspitze ozone is $1 \%$. Ultraviolet absorption instruments have been employed (Thermo Electron Corporation, U.S.A., TE49 analysers). Relative humidity (RH) was registered with a dew-point mirror (Thygan VTP6, Meteolabor, Switzerland) with a quoted uncertainty below $5 \%$ RH. However, the instrument has a wet bias of almost $10 \%$ under very dry conditions (Trickl et al., 2014). The Zugspitze measurements were discontinued in January 2013.

After the end of these measurements we have used the corresponding data of the Global Atmosphere Watch (GAW) observatory at the Schneefernerhaus research station (UFS, see $\mathrm{H}_{2} \mathrm{O}$ lidar), operated by the German Umweltbundesamt (UBA, i.e., Federal Environmental Agency; 47 25' 0" N, $11^{\circ} 58^{\prime} 46^{\prime \prime}$ E; air inlet at $2670 \mathrm{~m}$ a.s.1.). Ozone is continuously measured by ultraviolet (UV) absorption at $254 \mathrm{~nm}$ (Thermo Electron Corporation, model Ts49i). Relative humidity is measured by the German Weather Service with an EE33 humidity sensor (E+E Elektronik). The calibration of the UBA instrumentation is routinely verified as a part of the GAW quality assurance efforts. The instruments are controlled daily and serviced on all regular work days.

For the comparisons shown in the figures of this paper we use time averages up to one hour because of the time delay of the air mass between UFS and IFU. In the presence of nearby vertical steps in the ozone distribution orographic lifting must be taken into consideration that can lead to vertical displacements.

\subsubsection{Sonde data}

25 Radiosonde data are routine used for calculating the atmospheric density, which is necessary for quantitative aerosol retrievals and the conversion of the ozone or water-vapour number density to mixing ratio. Most importantly, on each measurement day of the ozone DIAL the presence of dry and moist layer was examined in view of an identification advection from a remote stratosphere or (marine) boundary layer. The sonde data have been imported from the University of Wyoming data base (http://weather.uwyo.edu/upperair/sounding.html). Preferentially, the Oberschleißheim ("Munich") sonde RH has been examined, this station (number: 10868) being located $100 \mathrm{~km}$ roughly to the north. If data were not available for a given time or if no indication of an intrusion was found RH profiles from other surrounding stations were used such as Stuttgart (10739, about 200 $\mathrm{km}$ to the north-west), Payerne (06610, about $310 \mathrm{~km}$ to the west), or Innsbruck (11120, $32 \mathrm{~km}$ to the south, one measurement per day only). In critical cases the station choice was also based on the trajectory results, and even more remote sites have been inspected.

The sonde type used by the German Weather Service (DWD, Deutscher Wetterdienst) during the period presented here was RS 92 (Vaisala; e.g., Miloshevich et al., 2006; Steinbrecht et al., 2008). The sonde data 
Atmos. Chem. Phys. Discuss., https://doi.org/10.5194/acp-2017-1192

feature an artificial cut-off at $1 \%$ for conditions when the UFS DIAL revealed even even much drier conditions (Trickl et al., 2014).

\subsection{Models}

\subsubsection{LAGRANTO}

Four-day forward trajectories have been calculated once a day for start times $\mathrm{t}_{0}=1: 00$ CET (Central European Time, $=\mathrm{UTC}+1 \mathrm{~h}), \mathrm{t}_{0}+12 \mathrm{~h}, \mathrm{t}_{0}+14 \mathrm{~h}$ and $\mathrm{t}_{0}+36 \mathrm{~h}$ based on the Lagrangian Analysis Tool (LAGRANTO; Wernli and Davies, 1997a; Sprenger and Wernli, 2015) since summer 2000. On each day, trajectories are calculated using operational forecast data from the European Centre for Medium-Range Weather Forecasts (ECMWF) interpolated to with $1^{\circ} \times 1^{\circ}$ horizontal resolution. For each start time four-day forward trajectories are calculated, starting in the entire region covering the Atlantic Ocean and Western Europe $\left(20^{\circ}\right.$ east to $80^{\circ}$ west and $40^{\circ}$ to $80^{\circ}$ north) between 250 and 600 mbar. From this large set of trajectories those initially residing in the stratosphere (potential vorticity larger than $2.0 \mathrm{pvu}$ ) and descending during the following four days by more than 300 mbar into the troposphere were selected as "stratospheric intrusion trajectories". The same selection criterion was used in a previous case study (Wernli, 1997b) to study an intrusion associated with a major North Atlantic cyclone.

Since June 2001 so-called "intrusion hit tables" have been additionally distributed giving a crude estimate of the time-height development of stratospheric air above the four STACCATO (Stohl et al., 2003) partner stations Jungfraujoch, Zugspitze, Monte Cimone and Thessaloniki over several days. Both the STT trajectories and the hit tables are daily distributed to all interested partners and institutions. Intrusion warnings based on these images have been issued by IFU if several of the stations could be affected (Zanis et al., 2003b).

For special case studies LAGRANTO has been operated with re-analyses meteorological data, for periods up to five days (e.g., Trickl, 2014; 2016). The three-dimensional wind fields for the calculation of the trajectories were taken from ERA-Interim data set (Dee et al., 2011) from ECMWF, which was interpolated to a with $1 \times 1$ horizontal resolution and provides winds at 6-h intervals.

\subsubsection{HYSPLIT}

For analysing intrusion events with travel times exceeding the four days set in the LAGRANTO forecast runs or with source regions outside the domain of the forecasts we use HYSPLIT (Hybrid Single-Particle Lagrangian Integrated Trajectory, Draxler and Hess, 1998; http://ready.arl.noaa.gov/HYSPLIT.php) backward trajectories. The three-dimensional ("model vertical velocity") backward trajectory calculations were preferentially based on 30 re-analysis meteorological data. Although the re-analysis data are coarser than other meteorological data available they have led to a superior model performance in the free troposphere in many of our studies (Trickl et al., 2010; 2013; 2014; Fromm et al., 2010) and the analysis of our routine measurements: Despite the known limitations of backward trajectories (e.g., Stohl and Seibert, 1998) most specific free-tropospheric layers in years of observations could be related to reasonable sources with this operation mode of HYSPLIT, the best

35 investigated transport type being STT. Since 2014 near-real-time data evaluation and aerosol archiving in the EARLINET (European Aerosol Research Lidar Network, https://www.earlinet.org) data base have been achieved. Thus, GDAS-based trajectories (GDAS: Global Data Assimilation System) have been taken since the 
re-analysis-based model version are available only with considerable delay. In a number of cases the GDASbased trajectories did not verify STT. However, later runs in the re-analysis mode for the present study clearly verified a stratospheric origin of the air mass of interest (see also Trickl et al., 2015).

The calculations were extended to the full 315 -h period supported by the model. In very rare cases the trajectories did not end in an altitude range corresponding to expectations for the lower stratosphere in the outflow region of an intrusion (e.g., roughly $7.5 \mathrm{~km}$ or more in boreal regions) within $315 \mathrm{~h}$. In some these cases extension trajectories were calculated to verify the stratospheric source (Trickl et al., 2015). Otherwise, these cases were rejected.

Slight vertical displacements of intrusion layers at the northern rim of the Alps exist in the model runs as reported previously (Trickl et al., 2010; 2015). These offsets, that vary from case to case, are explained by the insufficiently resolved orography that leads to an altitude of IMK-IFU (730 m a.s.l.) roughly half-way between the valley (Garmisch-Partenkirchen) and the Zugspitze summit. It is important to activate the check box "terrain" on the HYSPLIT input page together with the altitude option "AMSL" (above mean sea level). In this case, the absolute height is used on the vertical axis as well as the contour of mountains are displayed, and better agreement with the altitude of an arriving atmospheric layer is achieved. The trajectories are lifted above mountain ranges, which is particularly spectacular above Greenland with a surface altitude of about $3 \mathrm{~km}$ maintained over hundreds of kilometres.

\section{Results}

\subsection{Description of the data analysis and interpretation}

20 Starting in 2007, routine measurements have been started with both DIAL systems. This has yielded vertical profiles of ozone, water vapour and aerosol backscatter coefficients, derived from the 313-nm channel of the ozone DIAL. The number of measurements is particularly high in the case of the ozone lidar, resulting in a total of 2275 evaluated data files between 2007 and 2016 (Table 1). The present study is, therefore, based on the ozone soundings during this period and all other data are used for identifying the source for conspicuous ozone structures such as stratospheric air intrusions. Measurements have been made on a large number of fair-weather days or during short periods of clearing. However, really strong efforts to make at least one measurement were limited to the EARLINET (European Aerosol Research Lidar Network) "climatology days" Monday and Thursday (EARLINET, 2003). Ancillary information from sondes and trajectories has been gathered for each measurement day.

30 There are several gaps in the data. These gaps are explained by extended periods of laser or computer damage, sometimes involving the search for new technical solutions for the system. The latest one occurred between August 2016 and September 2017. The temporal co-incidence of ozone and $\mathrm{H}_{2} \mathrm{O}$ measurements had gradually grown before the fatal laser damage of the Ti:sapphire laser in early 2015 (a new laser is under development). Layers with elevated ozone were analysed either for the existence of a positive forecast with LAGRANTO and/or with HYSPLIT trajectories. For HYSPLIT, potential vorticity has not been available for identifying the tropopause and, thus, descent from roughly $7.5 \mathrm{~km}$ ore more (preferentially at higher latitudes) was looked for. This altitude had been found to be sufficient from previous analyses and the LAGRANTO calculations that select stratospheric trajectories based on potential vorticity. With decreasing latitudes and in summer higher start 
Atmos. Chem. Phys. Discuss., https://doi.org/10.5194/acp-2017-1192

Manuscript under review for journal Atmos. Chem. Phys.

Discussion started: 29 January 2018

(c) Author(s) 2018. CC BY 4.0 License.

altitudes preferred. At the same time low lidar or sonde relative humidity (RH) with minimum values clearly below $10 \%$ had to co-exist at least at adjacent altitudes. This was fulfilled for most cases, $8-10 \% \mathrm{RH}$ being the exception. In confirmation of our results from the water-vapour DIAL (Trickl et al., 2014; 2015; 2016) we found in the sonde data typical minimum RH values of 1-2 \% for source regions over the North Atlantic (intrusion Types 1-5 as defined by Trickl et al. (2010)), $1 \%$ being the lowest value found in the sonde listings (Sect. 2.1.4). For long-range descent from a remote stratospheric source (e.g., western Canada, Alaska, Siberia: Type 6) or slow descent from the North Atlantic minimum RH mostly ranged between 3-6\%. It is interesting to note that, reversely, finding RH values in this range in sonde data with great reliability led to very long transport times. Quite surprisingly, the longest descent analysed (15-17 days) led to negligibly low $\mathrm{H}_{2} \mathrm{O}$ in the DIAL measurements at UFS (July 16, 2013: Trickl, 2015).

Intrusions reaching altitudes around $3 \mathrm{~km}$ were verified by looking at the Zugspitze ozone and RH data until 2010 and the UFS data afterwards. As pointed out in Sect. 2.1.3 the Zugspitze RH rarely dropped clearly below $10 \%$.

Range of ozone values in intrusion layers was between 5-10\% above the background (last figure of Trickl et al., 2014) and $235 \mathrm{ppb}$ (see below). The smallest enhancements could be identified due to the strongly improved data quality of the ozone DIAL. Just a few cases had to be rejected either due to insufficient dryness or not not fully conclusive trajectory results. Sometimes these weak structures were looked for only after finding strong evidence of a very dry layer in the daily inspected humidity data and after a verification with trajectories.

In winter, in the absence of strong photochemical ozone production, the existence of a pronounced ozone peak in the vertical profile is, of course, highly indicative of the presence of stratospheric air.

\subsection{Typical findings}

As previously discussed (Trickl et al., 2010) stratospheric air intrusions passing over Garmisch-Partenkirchen arrive from almost all directions. Easterly directions mostly result from detours of the dry layers via Eastern Europe or curl formation over Central Europe potentially in cut-off lows. A few HYSPLIT results some rather complex pathways.

It is interesting that intrusion layers can be observed under so many different conditions. We routinely observe pre-fontal and post-frontal intrusion layers, as well as intrusions slowly descending from the far west. The first prefrontal ozone peak was detected above Garmisch-Partenkirchen just ahead of the 1997 VOTALP Föhn case (Seibert et al., 2000). These cases are frequently associated with a descent of the stratospheric air masses from the Arctic to North Africa followed by some return to Central Europe, accompanied by Saharan dust. These layers normally rise as a function of time as they are on a transition into a warm conveyor belt (e.g., Cooper et al., 2004). Postfrontal intrusions have been more frequently studied. They mostly reach low altitudes above Garmisch-Partenkirchen and occur very reliably, of course in the "classical" case of beginning anti-cyclonic conditions (e.g., Stohl and Trickl, 1999; Trickl et al., 2003), but even between two fronts sometimes separated by not more than one day. In these cases the inclined descending layer can be sandwiched between the low-lying clouds of the preceding front and the high-lying clouds of the incoming new front. 
Atmos. Chem. Phys. Discuss., https://doi.org/10.5194/acp-2017-1192

A few specific remarks:

(1) Very intense intrusions have been rare

Although intrusions with $100-150 \mathrm{ppb}$ of ozone in the middle and upper troposphere are not that rare much higher values are really exceptional. Just three cases with peak ozone mixing ratios reaching or exceeding $200 \mathrm{ppb}$ have been found during the period described here. The most intense intrusion case was observed on 1 October 2015 (Fig. 2). The peak ozone mixing ratio on that day was 235 ppb. The high ozone values did not last long. The peak ozone values rapidly dropped to less than $100 \mathrm{ppb}$. For comparison we give average values of the in-situ GAW measurements at UFS (2670 m). The UFS data exhibit a slight negative bias of 2 to $5 \mathrm{ppb}$ which, given the normally better agreement, is ascribed to orographic lifting of the air masses that arrived from the east (see below), along the former glacier basin.

The presence of an intrusion on 1 October 2015 had been predicted by the LAGRANTO operational forecasts. For this paper the trajectory calculations were repeated with re-analysis data (ERA Interim) at intervals of just six hours and extended to five days. In Fig. 3, we give one example for a start time of 12 UTC (13 CET) on 25 September. This start time is slightly too early with respect to the lidar observations. However, the trajectory plots for the later times become more and more complex with streamers for quite different arrival times over Central Europe confusing the picture. The structures in Fig. 3 persist in addition to the new trajectory bundles.

Figure 3 and later plots show high-lying and low-lying trajectories over South Germany and qualitatively confirm the observations. Some more clearness comes from the HYSPLIT backward trajectories that allow one to separate in time and altitude above the lidar. The HYSPLIT calculations (not shown) nicely confirm the main pathway shown in Fig. 3 with a northward departure over Greenland followed by a decent via Eastern Europe.

(2) 235 ppb were also observed on 26 February 2015 (at $7 \mathrm{~km}$ ), and a particularly spectacular case with $200 \mathrm{ppb}$ was reported for March 6, 2008 (Trickl et al., 2014). Extremely thin layers survive the long-range transport with almost negligible mixing with tropospheric air

The width of intrusion layers can vary considerably from case to case. Layer widths exceeding 1 to $2 \mathrm{~km}$, in particular that in Fig. 2, are rare. However, the simultaneous presence of several dry layers is quite frequent as shown in our earlier work (e.g., Zanis et al., 2003b; Trickl et al., 2010). Also very thin layers with widths of down to $0.2 \mathrm{~km}$ have been observed. Both IFU DIAL systems are capable of resolving these structures, and there is mostly very little mixing with tropospheric air (Trickl et al., 2014; 2015; 2016). A particularly spectacular case (26-27 December 2008) was discussed by Trickl et al. (2014) and verified by highresolution transport modelling. Here, we show as an example two parallel thin high-ozone layers descending to Alpine summit levels (Fig. 4).

(3) Slow long-distance descent (Type 6) dominates the observations above about $4.5 \mathrm{~km}$

The slow descent of stratospheric layers from remote source regions such as Western Canada, Alaska or even Siberia down to Alpine summit levels was identified by Trickl et al. $(2010 ; 2015)$. These Type 6 intrusions (definition: Trickl et al., 2010) are shown here to become even more important if one looks at the entire free troposphere. A source can also be the subtropical jet stream on its way across Asia, reaching midand high latitudes over the Pacific Ocean (Trickl et al., 2011). 
(4) Intrusion layers arriving via North Africa ahead of a long front are mostly not mixed with Saharan dust because they are typically located above the dust layer (exceptions exist). In Fig. 5 we show time series of the ozone aerosol profiles on 31 January and 1 February 2014, and Fig. 6 displays three HYSPLIT trajectories selected for the three relevant ozone and aerosol layers at midnight between the two days. The dust was lifted to roughly $5 \mathrm{~km}$ which is typical of these Föhn events at the northern rim of the Alps (e.g., Jäger et al., 1988; Papayannis et al., 2008). Above the dust layers a layer with elevated ozone passed over our site. The minimum Munich RH on 1 February at 1 CET was $2 \%$ indicating a moderate travel time (the UFS DIAL was not operated). The intrusion trajectory in Fig. 6 shows rather rapid travel from about $10 \mathrm{~km}$ above Cape Farvel (Greenland) to North Africa. Obviously, this high speed makes it possible to pass eastward over the southern part of the front and enter the air stream rising to the Alps. The HYSPLIT trajectories for other altitudes around $7 \mathrm{~km}$ start to differ strongly vertically and horizontally upstream Eastern Canada. The LAGRANTO STT forecast confirms at least transport from Labrador to North Africa.

Another dust case this time combined with long-range descent from the Northern United States (U.S.) (and presumably beyond) and a single-loop curl at low latitudes (see (7)) is shown in Fig. 7 (18 June 2013), with a corresponding trajectory analysis in Fig. 8. Here, the intrusion air mass crossed the cold front over Western Spain or Portugal. At 13 CET on 18 June this front extended north-south from Bristol (U.K.) to North Africa. Obviously, the upper end of the clouds was rather low in this area, similar to the May-1996 case in (Trickl et al., 2003). The RH determined from a comparison of the results of the water-vapour DIAL (right panel in Fig. 7) and the Munich radiosonde was 8 to $12 \%$. These rather high values are ascribed to the very long descent over at least thirteen days.

Intrusions co-existing with Saharan dust have been observed on a total of 67 days. The number of dust days in our record is limited because frequently dust arrives below clouds and not always lidar measurements have been made.

(5) Elevated summer-time ozone above about $4.5 \mathrm{~km}$ was a feature observed many times. Two examples from May and August 2015 are shown in Fig. 9. In both cases (and most others) dry layers exist within the highozone range and the corresponding HYSPLIT trajectories stay at high altitudes. For the altitudes analysed with trajectories we did not find any contact with potentially polluted planetary boundary layer (PBL) within the maximum of $315 \mathrm{~h}$ provided by the model. However, the calculation for a cirrus layer around $7.5 \mathrm{~km}$ on 10 August ended around $5 \mathrm{~km}$ over the Pacific, giving some hint on the origin of the moisture.

The quality of the lidar measurements in the upper troposphere was reduced due to the elevated absorption of the radiation by ozone. The vertical range was slightly larger during the darker hours.

(6) Volcanic and fire aerosol are transported downward from the lowermost stratosphere

During the periods of major volcanic activity impacting the lower stratosphere frequently aerosol was detected in intrusion layers (see also Browell et al., 1987). More specifically, particles in intrusion layers were registered after the eruptions of Okmok and Kasatochi (July and August 2008, respectively; see (Trickl et al., 2016)), Redoubt (March 2009), Sarychev (June 2009) and Nabro (June 2011) (more details: Trickl et al., 2013). Typical 313-nm aerosol backscatter coefficients were $5 \times 10^{-7} \mathrm{~m}^{-1} \mathrm{sr}^{-1}$ and less. The highest value was $2.35 \times 10^{-6} \mathrm{~m}^{-1} \mathrm{sr}^{-1}$, observed on 7 September 2009, after the violent eruption of Sarychev. Stratospheric intrusions have been seen as a highly important mechanism for the rapid depletion of stratospheric aerosol in 
Atmos. Chem. Phys. Discuss., https://doi.org/10.5194/acp-2017-1192

the mid-latitudes of one year or less (Deshler, 2008; Trickl et al.. 2013). This includes strong fires (pyroCbs) that normally just reach the lowermost stratosphere (e.g., Fromm et al., 2008; 2010), the latest presumable smoke case being 2 October 2017 (not shown).

(7) Lower-latitude Atlantic

5

3.3 Statistical analysis of STT layer boundaries cannot always be clearly distinguished. Water-vapour profiles show a clearer contrast, but rarely match in time. The soundings with the $\mathrm{H}_{2} \mathrm{O}$ DIAL were frequently not made on the same day, and sonde data are just a qualitative tool due to the long distance to the stations.

As a consequence we decided to prepare a statistical analysis of the fraction of the measurement days with identified intrusion layers (Sec. 3.1) similarly to the approach by Beekmann et al. (1997). The seasonal cycle from our analysis is shown in Fig. 10. It was derived from all measurement days (585) and intrusion days for each month between 2007 and 2016. The variability is rather low. In order to derive an estimate of its magnitude we derived a standard deviation from months with at least eight measurement days. Since the number of months fulfilling this condition was rather limited the overall standard deviation was 0.12 , i.e., much higher than expected from the smoothness of the data in Fig. 10. From a visual inspection of the data we would expect roughly half this value.

The variability is obviously much higher when taking just the data for Monday and Thursday, i.e., the EARLINET "climatology days" (286). Nevertheless, the principal seasonal cycle is retained. Just for the period December to February the deviations are larger due to a smaller number of climatology days covered.

35 Similarly to Beekmann et al. (1997) we find a rather constant seasonal cycle of the fraction of intrusion days. However, our average fraction of $84.1 \%$ is much higher than that in their study ( $4.8 \%$ for Uccle, Belgium). We discuss this fact in Sect. 4. A slight seasonal maximum is visible in Fig. 10 around August, resembling the findings by Beekmann et al. (1997) for the observational criteria used in their study. 
Atmos. Chem. Phys. Discuss., https://doi.org/10.5194/acp-2017-1192

Considering the pronounced summer minima obtained for the Alpine summit stations Jungfraujoch (3580 $\mathrm{m}$ ), Zugspitze (2962 m), Sonnblick (3106) and the station Mte. Cimone $(2165 \mathrm{~m})$ in the North Italian Apennines (Stohl et al., 2000; Trickl et al., 2010) a rather high stratospheric fraction for the full free troposphere looks reasonable to account for the strong difference in seasonal cycle. For comparison, we give in Fig. 10 the fraction of days on which $3.0 \mathrm{~km}$ was reached. In addition, the analysis for the Zugspitze summit for 2001-2005 is shown, converted from the highest values of Trickl et al. (2010) for their new filtering criteria (neglecting the difference between "number of cases" and "number of days"). The distributions agree rather well. However, the lidar-based fractions are rather noisy due a moderate number of measurements days. This may have influenced the deviations from the Zugspitze analysis for January and March. However, since 2008 rather cold winters have prevailed and could have led to less frequent deep intrusions in January. This possibility must be investigated further. The March maximum in the Zugspitze fraction was caused by an elevated count of six and four deepintrusion days in March 2014 and 2015, respectively. These were the only years with a reasonable number of measurement days in March which could suggest the occurrence of a positive outlier. On the other hand the FLEXPART simulation in Fig. 1 of Trickl et al. (2010), made for 1995-1999, shows a pronounced maximum in March.

The peak ozone mixing ratio in intrusion layers can vary considerably. High ozone values beyond $100 \mathrm{ppb}$ are mostly limited to altitudes above $5 \mathrm{~km}$. However, very recently (on 3 November 2017) we found as much as 95 ppb of ozone in a layer centred at $3.0 \mathrm{~km}$ and featuring a full width at half maximum of just $0.2 \mathrm{~km}$. In order to see if there is seasonal variation we determined the seasonal cycle of the "weak" and "strong" intrusions in the free troposphere (Fig. 11). The intrusions for which the peak ozone values exceeded the neighbouring ozone "background" by less than 15 ppb exhibit a summer minimum, whereas those with an exceedance of more than $40 \mathrm{ppb}$ a summer maximum, with some contribution also from January to April. Trickl et al. $(2014 ; 2016)$ hypothesized that the peak ozone concentration is related to how far the separating layer initially extends into the stratosphere. In this picture the initial layer thickness is most pronounced in summer.

25 Lidar observations are restricted to fair-weather conditions. Thus, the fractions derived here potentially exhibit some fair-weather bias. To estimate the influence we select the year 2014, which was the only year with full coverage of all months. At the same time $70 \%$ of the EARLINET climatology days were covered by measurements. The same high fraction of intrusion days was found as for the entire period. The missing $30 \%$ of climatology days were almost exclusively due to measurements prevented by bad weather. If one assumes that no intrusion has been present on bad-weather days (which is not fully true according to the model-based predictions), the overall fraction sinks from 0.841 to 0.59 which is, still, quite remarkable. Again taking 2014 we derived a crude estimate of the average stratosphere ozone fraction in the free troposphere detectable by its peak structure. We obtained a value of $18 \%$ (varying from roughly $12 \%$ in winter to roughly $26 \%$ in summer), taking into account the estimated area of ozone in the combined intrusion layers in comparison to the thermal tropopause on a given day and the the lower-tropospheric "background" mixing ratio. This analysis cannot assess the role of stratospheric ozone fully mixed into the troposphere since this contribution does not give rise to a discernible structure. This indirect contribution cannot be estimated without model assistance. For the Zugspitze summit an estimate of the indirect component was made based on the ${ }^{7} \mathrm{Be}$ measurements (Fig. 1) that lead to an overall annual stratospheric ozone fraction of the order of $40 \%$ for the first years after 2000 . 
Atmos. Chem. Phys. Discuss., https://doi.org/10.5194/acp-2017-1192

The overall seasonal cycle in Fig. 10 is dominated by Type 6 intrusions, i.e., intrusions that originate in source regions far to the west including Siberia. Most of these intrusions descend to just about 4.5 to $5 \mathrm{~km}$, are, thus, missed at the Alpine stations.

\subsection{Trans-Atlantic transport}

5 During the observational period most pronounced elevated-ozone features in the middle and upper troposphere were mainly related to the presence of very dry air. Clear examples of trans-Atlantic transport of high levels of ozone as during the observational period between 1996 and 2003 have been identified, but have been rare in recent years. Also during that period the possibility of additional stratospheric components was carefully examined in various case studies, and we were able to distinguish these contributions (e.g., Trickl et al., 2003; 2010; 2011). In our current effort we have not routinely analysed ranges of the distribution without pronounced ozone maxima. In principle, this fact could mean an improved air quality over North America.

During the warm season frequently a step-like ozone rise has been observed, typically above $5 \mathrm{~km}$ and contain dry layers (e.g., Fig. 9). Mostly, the trajectories stay high above North America and are of Type 6 or coming from Asia suggesting potential input from the subtropical jet stream as published by Trickl et al. (2011).

15 However, on 28 May 2015 a major part of that step could be related to a spectacular ozone episode in the Eastern U.S. The ozone profiles from that day are displayed in Fig. 12. At almost all tropospheric altitudes there were (in part remarkable) changes in ozone that could be explained by the RH and trajectory analyses. In the morning two intrusion layers from source regions around Alaska are seen at about 4.7 and $3.1 \mathrm{~km}(\mathrm{RH}=6 \%$ and $4 \%$, respectively). The trajectories seem to continue rising for times beyond $-315 \mathrm{~h}$, to altitudes higher than $7 \mathrm{~km}$.

These intrusions diminish later on.

In the afternoon an ozone step to roughly $80 \mathrm{ppb}$ formed above $6.7 \mathrm{~km}$. The air mass was rather humid (RH 50$75 \%$, some backscatter profiles showed signal from cirrus clouds), with the exception of the lowest peak for which the Munich radiosonde yielded $\mathrm{RH}=4 \%$ (there at $7.6 \mathrm{~km}$ ). Figure 13 shows three 315 -h HYSPLIT backward trajectories selected for relevant altitudes above our site $(7400 \mathrm{~m}, 8200 \mathrm{~m}, 8500 \mathrm{~m})$. The ozone rise towards $7 \mathrm{~km}$ corresponds to long-range descent from northern Alaska, in agreement with the low RH.

The higher trajectories bend southward over the Great Lakes and follow the Mississippi back to the Caribbean Sea. On 24 May an altitude of $1.5 \mathrm{~km}$ is reached, i.e., above Louisiana. The strong air-mass rise from the Gulf of Mexico to Canada suggest the presence of a warm conveyor belt. To the east a wide zone with peak ozone exceeding $80 \mathrm{ppb}$ is revealed in Fig 14 indicating long-lasting high pressure. The trajectories propagate along the west side of that zone and indicate some overlap with the high-ozone region. This result is highly satisfactory and confirms our excellent experience with HYSPLIT run with the re-analysis option. In fact, we also tested the GDAS option that offers better resolution. As in earlier comparisons (e.g., Trickl et al., 2016), we found strong deviations, with almost all trajectories leading backward to Alaska at high altitudes, approximately parallel to the red 7400-m trajectory in Fig. 13. This result is in considerable disagreement with the RH data that show just a narrow dry layer above $7 \mathrm{~km}$ and elevated humidity at higher altitudes that is in excellent agreement with the import from the Caribbean Sea suggested in Fig. 13 and the cirrus signal in the lidar data. 


\section{Discussion and Conclusions}

The very large fracton of stratospheric intrusion days in our lidar measurements is an enormous surprise. The observed average percentage of $83.8 \%$ of all measurement days in the free troposphere since 2007 strongly exceeds the average fraction of about $17 \%$ observed at the Zugspitze summit (2962 m) between 2001 and 2005 (Trickl et al., 2010). It also exceeds the $27 \%$ of temporal coverage by tropopause folds determined from lidar measurements at the Table Mountain Facility in Southern California between 2000 and 2015 (Granados-Muñoz and Leblanc, 2016), located at much lower latitude. However, the Table Mountain seasonal cycle peaks at about $70 \%$ in winter and, during that period, almost matches our fraction. From July to September it minimizes at 1 to $2 \%$, in qualitative agreement with the minimum of the STJ found by Sprenger et al. (2003), this jet stream most likely being more relevant above that observational site during the warm season.

The absence of a pronounced summer minimum in the free tropospheric seasonal cycle as in the Alpine summitstation data suggests the existence of a strong summer maximum of the transport pathways leading to the seasonal cycle derived. This transport pattern is dominated by slow descent from Canada, Alaska and Siberia (Type 6 as defined by Trickl et al. (2010)). These pathways can differ and not always point to a smooth anticyclonic behaviour as hypothesized for the intense boreal fire plumes (e.g., (Forster et al., 2001; Trickl et al., 2015). The trajectories frequently indicate wavelike transport paths, but mostly without strong re-ascent in the cyclonic sections. This kind of long-range descent, its underlying dynamics and its influence on the STT budget call for a meteorological explanation. It would also be interesting to determine how much an extension of the transport calculations to about fifteen days would change the STT budget with respect to earlier work (e.g., Sprenger et al., 2003; Škerlak, et al., 2014).

Beekmann et al. (1997) also found a missing summer minimum for tropopause folds determined in their analysis of sonde data for different periods around 1990. The derived tropopause fold fraction of about $5 \%$ is clearly smaller than the stratospheric fractions obtained in the present study and for Table Mountain. However, the data selection criteria in the 1997 assessment were stricter than in the present study. For example, the selection of cases by the observational groups in that effort was based on an ozone increase by at least $25 \%$, a potentialtemperature gradient of more than $11.5 \mathrm{~K} / 100 \mathrm{mbar}, \mathrm{RH}<25 \%$ and a wind speed of more than $20 \mathrm{~m} \mathrm{~s}^{-1}$. In addition, the vicinity of an upper tropospheric jet stream and co-incidence with an upper-level front was asked for. It is obvious that the difference in ozone and RH thresholds alone cannot explain the huge discrepancy in the fractions. The additional criteria could exclude many of the aged intrusions that originate over rather remote regions and dominate our observations in the middle and upper troposphere. For example, the trajectory results for Type- 6 intrusions frequently yield a wind speed of the order of $1000 \mathrm{~km}$ in $24 \mathrm{~h}\left(11.6 \mathrm{~km} \mathrm{~m}^{-1}\right)$ during the approach to Central Europe. One additional possibility is that the 1997 analysis focussed just on isolated peaks which could exclude the wider structures we observed in the middle and upper troposphere. On the other hand this could mean a summer minimum in the 1997 results which was not the case. In addition, a potential increase in STT frequency between the 1990s and recent years. The Zugspitze in-situ results (Fig. 1), which reveal most of the increase in deep STT occurred between the 1970s and 2000, suggest that such a contribution is less important.

A quantification of the stratospheric fraction of tropospheric ozone from our data is difficult. On one hand, the true extent of the layers can be better derived from the water-vapour profiles, but so far the DIAL measurements 
Atmos. Chem. Phys. Discuss., https://doi.org/10.5194/acp-2017-1192

Manuscript under review for journal Atmos. Chem. Phys.

Discussion started: 29 January 2018

(c) Author(s) 2018. CC BY 4.0 License.

at UFS have not sufficiently overlapped with the ozone soundings for such an effort. For 2014 a crude estimate was made that suggested a stratospheric ozone fraction of roughly $18 \%$ for layers that can be directly identified. On the other hand, just the directly detected intrusions can be used. Aged stratospheric air that has completely mixed into the troposphere cannot be identified by simultaneous ozone and water-vapour profiling. A modelbased approach is needed. At the Zugspitze summit specific tracers can be registered and ${ }^{7} \mathrm{Be}$ was used as a tracer of strongly descending air (Fig. 1). These measurements do not exhibit a fair-weather bias. Although the half-value time of this isotope of about 53 days is limited a reasonable estimate could be made. We plan to revise now this quantification based on the experience gained during the past ten years.

Certainly, improved modelling will be needed to quantify STT. So far, Eulerian models have had difficulties in reproducing the strong ozone rise at the Alpine sites (e.g., Parrish et al., 2014; Staehelin et al., 2017). The calculated rise reported by Parrish et al. (2014) and Staehelin et al. (2017) ends almost 20 years earlier than the observed one. This is in agreement with the missing ozone trend for the IFU site Wank a few kilometres east of Garmisch-Partenkirchen after 1980. This station is located at just $1780 \mathrm{~m}$ a.s.l. and is hit by less than one half of the stratospheric intrusions than the higher-lying Zugspitze (Elbern et al., 1997), which suggests deficits in the models used in determining deep STT. In Eulerian models higher spatial resolution is needed for reproducing deep STT (Roelofs et al., 2003; Trickl et al., 2010; Eastman and Jacob, 2017) as well as reduced tropospheric mixing (Trickl et al., 2014).

Trickl et al. (2014) concluded that most intrusions originate in the lowest layer above the dynamical tropopause. This was confirmed in the same paper by the almost negligible drop in Zugspitze CO in STT layers and was verified by LAGRANTO transport modelling of the LUAMI (Lindenberg upper-Air Methods Intercomparison) case (Trickl et al., 2015). The tropopause region is a mixture of stratospheric and tropospheric air and estimates of about $50 \%$ for each of the two components were made (Shapiro, 1980; Vogel et al., 2011). However, the stratospheric nature of the descending air mass can vary significantly, depending on the stratospheric residence time (Reiter et al., 1975). We find in our trajectory studies that not all air parcels stay in the lower stratosphere for a long period of time. Sometimes air masses descending to the Alps had stayed above the tropopause for less than a single day, after a pronounced rise even from low altitudes. All these facts must be taken into consideration in future efforts.

\section{Acknowledgements}

The authors thank H. P. Schmid for his interest and support. They acknowledge the technical assistance of H. Giehl and M. Perfahl as well as the great support by the UFS team. W. Steinbrecht provided ozone sonde data of the German Weather Service (DWD) for comparisons. B. Pierce helped us with an ozone analysis for the U.S. The development of the Zugspitze water-vapour DIAL has been funded by the Bavarian Ministry of Economics and German Bundesministerium für Bildung und Forschung within the programme Atmosphärenforschung 2000 (ATMOFAST project: Atmospheric Long-range Transport and its Impact on the Trace-gas Composition in the

Free Troposphere over Central Europe, (ATMOFAST, 2005)). The aerosol observations contribute to EARLINET (European Aerosol Research Lidar Network, currently partly founded by ACTRIS 2).

The service charges for this open access publication have been covered by a Research Centre of the Helmholtz Association. 
Atmos. Chem. Phys. Discuss., https://doi.org/10.5194/acp-2017-1192

\section{References}

EARLINET: A European Aerosol Research Lidar Network to Establish an Aerosol Climatology, Final Report, European Union, contract EVR1-CT1999-40003, J. Bösenberg (Co-ordinator) and V. Matthias, Eds., Reporting Period February 2000 to February 2003, Max-Planck-Institut für Meteorologie, Hamburg (Germany), Report No. 348, ISSN 0937 1060, 212 pp., 2003.

ATMOFAST: Atmosphärischer Ferntransport und seine Auswirkungen auf die Spurengaskonzentrationen in der freien Troposphäre über Mitteleuropa (Atmospheric Long-range Transport and its Impact on the Trace-gas Composition of the Free Troposphere over Central Europe), Project Final Report, T. Trickl, co-ordinator, M. Kerschgens, A. Stohl, and T. Trickl, subproject co-ordinators, funded by the German Ministry of Education and Research within the programme "Atmosphärenforschung 2000“, http://www.trickl.de/ATMOFAST.htm, 130 pp., 2005 (in German); revised publication list 2012

Beekmann, M., Ancellet, G., Blonsky, S., De Muer, D., Ebel, A., Elbern, H., Hendricks, J., Kowol, J., Mancier, C., Sladkovic, R., Smit, H. G. J., Speth, P., Trickl, T., and Van Haver, P.: Regional and Global Tropopause Fold Occurrence and Related Ozone Flux across the Tropopause, J. Atmos. Chem., 28, 29-44, 1997.

15 Browell, E. V., Danielsen, E. F., Ismail, S., Gregory, G. L., and Beck, S. M.: Tropopause Fold Structure Determined from Airborne Lidar and in Situ Measurements, J. Geophys. Res. 92, 2112-2120, 1987.

Carnuth, W. and Trickl, T.: Transport studies with the IFU three-wavelength aerosol lidar during the VOTALP Mesolcina experiment, Atmos. Environ., 34, 1425-1434, 2000.

Carnuth, W., Kempfer, U., and Trickl, T.: Highlights of the Tropospheric Lidar Studies at IFU within the TOR Project, Tellus B, 54, 163-185, 2002.

Collins, W. J., Derwent, R. G., Garnier, B., Johnson, C. E., Sanderson, M. G., and Stevenson, D. S.: Effect of stratosphere-troposphere exchange on the future ozone trend, J. Geophys. Res., 108, 8528, doi: 10.1029/2002JD002617, STA 13, 10 pp., 2003.

Cooper, O., Forster, C., Parrish, D., Dunlea, E., Hübler, G., Fehsenfeld, F., Holloway, J., Oltmans, S., Johnson, B., Wimmers, A., and Horowitz, L.: On the life cycle of a stratospheric intrusion and its dispersion into polluted warm conveyor belts, J. Geophys. Res., 109, D23S09, doi: 10.1029/2003JD004006, 18 pp., 2004.

Cristofanelli, P., Scheel, H.-E., Steinbacher, M., Saliba, M., Azzopardi, F., Ellul, R., Fröhlich, M., Tositti, L., Brattich, E., Maione, M., Calzolari, F., Duchi, F., Landi, T. C., Marinoni, A., and Bonasoni, P.: Long-term surface ozone variability at Mt. Cimone WMO/GAW global station (2165 m a.s.l., Italy), Atmos. Environ., 101, 23-33, 2015.

Danielsen, E. F.: Stratospheric-Tropospheric Exchange Based on Radioactivity, Ozone and Potential Vorticity, J. Atmos. Sci., 25, 505-518, 1968.

Danielsen, E. F., and Mohnen, V. A.: Project Dustorm Report: Ozone Transport, in Situ Measurements, and Meteorological Analyses of Tropopause Folding, J. Geophys. Res., 82, 5867-5877, 1977

35 Dee, D. P., Uppala, S. M., Simmons, A. J., Berrisford, P., Poli, P., Kobayashi, S., Andrae, U., Balmaseda, M. A., Balsamo, G., Bauer, P., Bechtold, P., Beljaars, A. C. M., van de Berg, L., Bidlot, J., Bormann, N., Delsol, C., Dragani, R., Fuentes, M., Geer, A. J., Haimberger, L., Healy, S. B., Hersbach, H., Hólm, E. V., Isaksen, L., 
Atmos. Chem. Phys. Discuss., https://doi.org/10.5194/acp-2017-1192

Kållberg, P., Köhler, M., Matricardi, M., McNally, A. P., Monge-Sanz, B. M., Morcrette, J.-J., Park, B.-K., Peubet, C., de Rosnay, P., Tavolato, C., Thépaut, J.-N., and Vitard, F.: The ERA-Interim reanalysis: Configuration and performance of the data assimilation system. Quart. J. Royal Meteorol. Soc., 137, 553-597, 2011.

Deshler, T.: A review of global stratospheric aerosol: Measurements, importance, life cycle, and local stratospheric aerosol, Atmospheric Research, 90, 223-232, 2008.

Draxler, R., and Hess, G.: An overview of the HYSPLIT_4 modelling system for trajectories, dispersion, and deposition, Aust. Meteorol. Mag., 47, pp. 295-308, 1998.

Eastman, S. D., and Jacob, D. J.: Limits on the ability of global Eulerian models to resolve intercontinental transport of chemical plumes, Atmos. Chem. Phys., 17, 2543-2553, 2017.

Eisele, H. and Trick1, T.: Second Generation of the IFU Stationary Tropospheric Ozone Lidar, in: Advances in: Atmospheric Remote Sensing with Lidar, Selected Papers of the 18th International Laser Radar Conference, Berlin (Germany), 22-26 July 1996, A. Ansmann, R. Neuber, P. Rairoux, U. Wandinger, Eds., Springer (Berlin, Heidelberg, Germany), 379-382, 1997.

15 Eisele, H., and Trickl, T.: Improvements of the aerosol algorithm in ozone-lidar data processing by use of evolutionary strategies, Appl. Opt., 44, 2638-2651, 2005.

Eisele, H., Scheel, H. E., Sladkovic, R., and Trickl, T.: High-resolution Lidar Measurements of Stratospheretroposphere Exchange, J. Atmos. Sci., 56, 319-330, 1999.

Elbern, H., Kowol, J., Sladkovic, R., and Ebel, A.: Deep stratospheric intrusions: A statistical assessment with model guided analysis, Atmos. Environ., 31, 3207-3226, 1997.

Fromm, M., Shettle, E. P., Fricke, K. H., Ritter, C., Trickl, T., Giehl, H., Gerding, M., Barnes, J., O’Neill, M., Massie, S. T., Blum, U., McDermid, I. S., Leblanc, T., and Deshler, T.: The stratospheric impact of the Chisholm PyroCumulonimbus eruption: 2. Vertical profile perspective, J. Geophys. Res., 113, D08203, doi: 10.1029/2007JD009147, 19 pp., 2008.

25 Fromm, M., Lindsey, D. T., Servranckx, R., Yue, G., Trickl, T., Sica, R., Doucet, P., and Godin-Beekmann, S.: The Untold Story of Pyrocumulonimbus, Bull. Am. Meterol. Soc., 91, 1193-1209, 2010.

Granados-Muñoz, M. J., and Leblanc, T.: Tropospheric ozone seasonal and long-term variability as seen by lidar and surface measurements at the JPL-Table Mountain Facility, California, Atmos. Chem. Phys., 16, 9299-9319, 2016.

30 Huh, C. A. , and Liu, L. G.: Precision measurements of the half-lives of some electron-capture decay nuclides: ${ }^{7} \mathrm{Be},{ }^{54} \mathrm{Mn},{ }^{83} \mathrm{Rb}$, and ${ }^{84} \mathrm{Rb}$, J. Radioanal. Nucl. Chem., 246, 229.231, 2000.

Jäger, H., Carnuth, W., and Georgi, B.: Observations of Saharan Dust at a North Alpine Station, J. Aerosol Sci., 19, 1235-1238, 1988

James, P., Stohl, A., Forster, C., Eckhardt, S., Seibert, P., and Frank, A.: A 15-year climatology of stratospheretroposphere exchange with a Lagrangian particle dispersion model 2. Mean climate and seasonal variability, J. Geophys. Res., 108, 8522, doi: 10.1029/2002JD002639, STA 7, 14 pp., 2003;

Jonson, J. E., Simpson, D., Fagerli, H., and Solberg, S.: Can we explain the trends in European ozone levels? Atmos. Chem. Phys., 6, 51-66, 2006. 
Atmos. Chem. Phys. Discuss., https://doi.org/10.5194/acp-2017-1192

Kempfer, U., Carnuth, W., Lotz, R., and Trickl, T.: A Wide-range UV Lidar System for Tropospheric Ozone Measurements: Development and Application, Rev. Sci. Instrum., 65, 3145-3164, 1994.

Kentarchos, A. S., and Roelofs, G. J.: A model study of stratospheric ozone in the troposphere and its contribution to tropospheric OH formation, J. Geophys. Res. 108, 8517, doi: 10.1029/2002JD002598, STA 2,9 pp., 2003.

Lal, D., and Peters, B.: Cosmic ray produced radioactivity on the earth, Handb. Phys., 46, 551-612, 1967 (as cited by Zanis et al., 2003a)

Lin, M., Fiore, A. M., Horowitz, L. W., Langford, A. O., Oltmans, S. J., Tarasick, D., and Rieder, H. E.: Climate variability modulates western US ozone air quality in spring via deep stratospheric intrusions, Nature Communications, 6:7105, doi: 10.1038/ncomms8105, 11 pp., 2015.

Logan, J. A., Staehelin, J., Megretskaia, I. A., Cammas, J.-P., Thouret, V., Claude, H., De Backer, H., Steinbacher, M., Scheel, H.-E., Stübi, R., Fröhlich, M., and Derwent, R.: Changes in ozone over Europe: Analysis of ozone measurements from sondes, regular aircraft (MOZAIC) and alpine surface sites, J. Geophys. Res., 117, D09301, doi: 10.1029/2011JD016952, 23 pp., 2012.

Miloshevich, L. M., Vömel, H., Whiteman, D. N., Lesht, B. M., Schmidlin, F. J., and Russo, F.: Absolute accuracy of water vapour measurements from six operational radiosonde types launched during AWEX-G and implications for AIRS validation, J. Geophys. Res., 111, D09S10, doi: 10.1029/2005JD006083, 25 pp., 2006.

Neu, J. L., Flury, T., Manney, G. L., Santee, M. L., Livesey, N. J., and Worden, J.: Tropospheric ozone variations governed by changes in stratospheric circulation, Nature Geoscience, 7, 340-344, 2014.

Nyeki, S., .Kalberer, M., Kolbeck, I., De Wekker, S., Furger, M., Gäggeler, W., Kossmann M., Lugauer, M., .Steyn, D., Weingartner, E., Wirth, M., and Baltensperger, U.: Convective Boundary Layer Evolution to 4 km asl over High-AlpineTerrain: Airborne Lidar Observations in the Alps, Geophys. Res. Lett, 27, 689-692, 2000.

Ojha, N., Naja, M., Sarangi, T., Kumar, R., Bhardway, R., Lal, S., Venkataramani, S., Sagar, R., Kumar, A., and Chandola, H. C.: on the processes influencing the vertical distribution of ozone over the central Himalayas: Analysis of yearlong ozonesonde observations, Atmos. Environ., 88, 201-211, 2014.

Ohja, N., Pozzer, A., Akriditis, D., and Lelieveld, J.: Secondary ozone peaks in the troposphere over the Himalayas, Atmos. Chem. Phys., 17 6743-6757, 2017.

Oltmans, S. J., Lefohn, A. S., Harris, J. M., Galbally, I., Scheel, H. E., Bodeker, G., Brunke, E., Claude, H., Tarasick, D., Johnson, B. J., Simmonds, P., Shadwick, D., Anlauf, K., Hayden, K., Schmidlin, F., Fujimoto, F., Akagi, K., Meyer, C., Nichol, S., Davies, J., Redondas, A., and Cuevas, E.,: Long-term changes in tropospheric ozone, Atmos. Environ., 40, 3156-3173, 2006.

Oltmans, S. J., Lefohn, A. S., Shadwick, D., Harris, J. M., Scheel, H. E., Galbally, I., Tarasick, D. W., Johnson, B. J., Brunke, E.-G., Claude, H., Zeng, G., Nichol, S., Schmidlin, F., Davies, J., Cuevas, E., Redondas, A., Naoe, H., Nakano, T., and Kawasato, T.: Recent tropospheric ozone changes - A pattern dominated by slow or no growth, Atmos. Environ., 67, 331-351 (2012).

Ordoñez, C., Brunner, D., Staehelin, J., Hadjinicolaou, P., Pyle, J. A., Jonas, M., Wernli, H., and Prévôt, A. S. H.: Strong influence of lowermost stratospheric ozone on lower tropospheric background ozone changes over Europe, Geophys. Res. Lett., 34, L07805, doi: 10.1029/2006GL029113, 5 pp., 2007. 
Atmos. Chem. Phys. Discuss., https://doi.org/10.5194/acp-2017-1192

Ott, L. E., Duncan, B. N., Thompson, A. M., Diskin, G., Fasnacht, Z., Langford, A. O., Lin, M., Molod, A. M., Nielsen, J. E., Pusede, S. E., Wargan, K., Weinheimer, A. J., and Yoshida, Y.: Frequency and impact of summertime stratospheric intrusions over Maryland during DISCOVER-AQ (2011): New evidence from NASA's GEOS-5 simulations, J. Geophys. Res., 121, 3687-3706, doi: 10.1002/2015JD024052, 2016.

Papayannis, A., Amiridis, V., Mona, L., Tsaknakis, G., Balis, D., Bösenberg, J., Chaikovski, A. De Tomasi, F., Grigorov, I., Mattis, I., Mitev, V., Müller, D., Nickovic, S., Pérez, C., Pietruczuk, A., Pisani, G., Ravetta, F., Rizi, V., Sicard, M., Trickl, T., Wiegner, M., Gerding, M., Mamouri, R. E., D'Amico, G., and Pappalardo, G.: Systematic lidar observations of Saharan dust over Europe in the frame of EARLINET (2000-2002), J. Geophys. Res., 113, D10204; doi:10.1029/2007JD009028, 17 pp., 2008.

10 Parrish, D. D., Law, K. S., Staehelin, J., Derwent, R., Cooper, O. R., Tanimoto, H., Volz-Thomas, A., Gilge, S., Scheel, H.-E., Steinbacher, M., and Chan, E., Long-term changes in lower tropospheric baseline ozone concentrations at northern mid-latitudes, Atmos. Chem. Phys., 12, 11485-11504, 2012

Parrish, D. D., Lamarque, J.-F., Naik, V., Horowitz, L., Shindell, D. T., Staehelin, J., Derwent, R., Cooper, O. R., Tanimoto, H., Volz-Thomas, A., Golge, S., Schell., H.-E., Steinbacher, M., and Fröhlich, M.: Long-term changes in lower tropospheric baseline ozone concentrations: Comparing chemistry-climate models and observations at northern midlatitudes, J. Geophys. Res., 119, 5719-5736, doi: 10.1002/2013JD021435, 2014.

Reiter, R.: The ozone trend in the layer of 2 to $3 \mathrm{~km}$ a.s.l. since 1978 and the typical time variations of the ozone profile between ground and 3 km a.s.1., Meteor. Atmos. Phys., 42, 91-104, 1990.

Reiter, R., Sládkovič, R., Pötzl, K., Carnuth, W., and Kanter H.-J.: Studies on the Influx of Stratospheric Air into the Lower Troposphere Using Cosmic-Ray Produced Radionuclides and Fallout, Arch. Met. Geoph. Biokl. A, 20, 211-246, 1971.

Reiter, E. R., Carnuth, W., Kanter, H.-J., Pötzl, K., Reiter, R., and Sládkovič, R.: Measurements of Stratospheric Residence Times, Arch. Met. Geoph. Biokl. A, 24, 41-51, 1975.

Reiter, R., Sladkovic, R., and Kanter, H.-J.: Concentration of Trace Gases in the Lower Troposphere,

Simultaneously Recorded at Neighboring Mountain Stations, Part II: Ozone, Meteorol. Atmos. Phys., 37, 27-47, 1987.

Roelofs G.-J., and Lelieveld, J.: Model study of the influence of cross-tropopause $\mathrm{O}_{3}$ transports on tropospheric $\mathrm{O}_{3}$ levels, Tellus B, 49, 38-55, 1997.

Roelofs, G. J., Kentarchos, A. S., Trickl, T., Stohl, A., Collins, W. J., Crowther, R. A., Hauglustaine, D.,

Klonecki, A., Law, K. S., Lawrence, M. G., von Kuhlmann, R., and van Weele, M.: Intercomparison of tropospheric ozone models: Ozone transport in a complex tropopause folding event, J. Geophys. Res. 108, 8529, doi:10.1029/2003JD003462, STA 14, 13 pp., 2003.

Scheel, H. E.: Ozone Climatology Studies for the Zugspitze and Neighbouring Sites in the German Alps, pp. 134-139 in: Tropospheric Ozone Research 2, EUROTRAC-2 Subproject Final Report, A. Lindskog, Coordinator, EUROTRAC International Scientific Secretariat (München, Germany, 2003); available at http://www.trickl.de/scheel.pdf.

Scheel, H. E., Areskoug, H., Geiß, H., Gomiscek, B., Granby, K., Haszpra, L., Klasinc, L., Kley, D., Laurila, T., Lindskog, A., Roemer, M., Schmitt, R., Simmonds, P., Solberg, S., and Toupance, G.: On the Spatial 
Atmos. Chem. Phys. Discuss., https://doi.org/10.5194/acp-2017-1192

Distribution and Seasonal Variation of Lower-Tropospheric Ozone over Europe, J. Atmos. Chem., 28, 11-28, 1997.

Seibert, P., Feldmann, H., Neininger, B., Bäumle, M., and Trickl, T.: South foehn and ozone in the Eastern Alps - case study and climatological aspect, Atmos. Environ., 34, 1379-1394, 2000.

Shapiro, M. A.: Turbulent Mixing within Tropopause Folds as a Mechanism for the Exchange of Chemical Constituents between the Stratosphere and Troposphere, J. Atmos. Sci., 37, 994-1004, 1980.

Škerlak, B., Sprenger, M., and Wernli, H.: A global climatology of stratosphere-troposphere exchange using the ERA-Interim data set from 1979 to 2011, Atmos. Chem. Phys., 14, 913-937, 2014.

Sprenger, M., and Wernli, H.: The LAGRANTO Lagrangian analysis tool - version 2.0, Geosci. Model. Dev., 8, 2569-2586, 2015.

Sprenger, M., Croci Maspoli, M., and Wernli, H.: Tropopause folds and cross-tropopause exchange: A global investigation based upon ECMWF analyses for the time period March 2000 to February 2001, J. Geophys. Res., 108, 8518, doi: 10.1029/2002JD002587, STA 3, 11 pp., 2003.

Staehelin, J. Tummon, F., Revell, L., Stenke, A., and Peter, T.: Tropospheric Ozone at Northern Mid-Latitudes:

Modeled and Measured Long-Term Changes, Atmosphere, 8, 163, 20 pp., 2017.

Steinbrecht, W., Claude, H., Schönenborn, F., Leiterer, U., Dier, H., and Lanzinger, E.: Pressure and Temperature Differences between Vaisala RS80 and RS92 Radiosonde Systems, J. Atmos. Oceanic Technol., 25, 909-927, 2008.

Stevenson, D. S., Dentener, F. J., Schultz, M. G., Ellingsen, K., van Noije, T. P. C., Wild, O., Zeng, G., Amann, M., Atherton, C. S., Bell, N., Bergmann, D. J., Bey, I., Butler, T., Cofala, J., Collins, W. J., Derwent, R. G., Doherty, R,. M., Drevet, J., Eskes, H. J., Fiore, A. M., Gauss, M.., Hauglustaine, D. A., Horowitz, L. W., Isaksen, I. S. A., Krol, M. C., Lamarque, J.-F., Lawrence, M. G., Montanaro, V., Müller, J.-F., Pitari, G., Prather, M. J., Pyle, J. A., Rast, S., Rodriguez, J. M., Sanderson, M. G., Savage, N. H., Shindell, D. T., Strahan, S. E., Sudo, K., and Szopa, S.: Multimodel ensemble simulations of present-day and near-future tropospheric ozone, J. Geophys. Res., 111, D08301, doi: 10.1029/2005JD006338, 23 pp., 2006.

Stohl, A., and Trickl, T.: A textbook example of long-range transport: Simultaneous observation of ozone maxima of stratospheric and North American origin in the free troposphere over Europe, J. Geophys. Res., 104, 30445-30462, 1999.

Stohl, A., and Seibert, P.: Accuracy of trajectories as determined from the conservation of meteorological tracers, Q. J. R. Meteorol. Soc., 124, 1465-1484, 1998.

Stohl, A., Spichtinger-Rakowsky, N., Bonasoni, P., Feldmann, H., Memmesheimer, M., Scheel, H. E., Trickl, T., Hübener, S., Ringer, W., and Mandl, M.: The influence of stratospheric intrusions on alpine ozone concentrations, Atmos. Environ. 34, 1323-1354, 2000.

Stohl, A., Bonasoni, P., Cristofanelli, P., Collins, W., Feichter, J., Frank, A., Forster, C., Gerasopoulos, E.,

35 Gäggeler, H., James, P., Kentarchos, T., Kromp-Kolb, H., Krüger, B., Land, C., Meloen, J., Papayannis, A., Priller, A., Seibert, P., Sprenger, M., Roelofs, G. J., Scheel, H. E., Schnabel, C., Siegmund, P., Tobler, L., Trickl, T., Wernli, H., Wirth, V., Zanis, P., and Zerefos, C.: Stratosphere-troposphere exchange - a review, and what we have learned from STACCATO, J. Geophys. Res., 108, 8516, doi:10.1029/2002JD002490, STA 1, 15 pp., 2003. 
Atmos. Chem. Phys. Discuss., https://doi.org/10.5194/acp-2017-1192

Trickl, T., Cooper, O. C., Eisele, H., James, P., Mücke, R., and Stohl, A.: Intercontinental transport and its influence on the ozone concentrations over central Europe: Three case studies. J. Geophys. Res., 108, 8530, doi:10.1029/2002JD002735, STA 15, 23 pp., 2003.

Trickl, T., Feldmann, H., Kanter, H.-J., Scheel, H. E., Sprenger, M., Stohl, A., and Wernli, H.: Forecasted Deep Stratospheric Intrusions over Central Europe: Case Studies and Climatologies, Atmos. Chem. Phys., 10, 499$524,2010$.

Trickl, T., Eisele, H., Bärtsch-Ritter, N. Furger, M., Mücke, R., Sprenger, M., and Stohl, A.: High-ozone layers in the middle and upper troposphere above Central Europe: potential import from the stratosphere along the subtropical jet stream, Atmos. Chem. Phys., 11, 9343-9366, 2011.

Trickl, T., Giehl, H., Jäger, H., and Vogelmann, H.: 35 years of stratospheric aerosol measurements at GarmischPartenkirchen: from Fuego to Eyjafjallajökull, and beyond, Atmos. Chem. Phys., 13, 5205-5225, 2013.

Trickl, T., Vogelmann, H., Giehl, H., Scheel, H. E., Sprenger, M., and Stohl, A.: How stratospheric are deep stratospheric intrusions? Atmos. Chem. Phys., 14, 9941-9961, 2014.

Trickl, T., Vogelmann, H., Flentje, H., and Ries, L.: Stratospheric ozone in boreal fire plumes - the 2013 smoke season over Central Europe, Atmos. Chem. Phys., 15, 9631-9649, 2015.

Trickl, T., Vogelmann, H., Fix, A., Schäfler, A., Wirth, M., Calpini, B., Levrat, G., Romanens, G., Apituley, A., Wilson, K. M., Begbie, R., Reichardt, J., Vömel, H. and Sprenger, M.: How stratospheric are deep stratospheric intrusions into the troposphere? LUAMI 2008, Atmos. Chem. Phys, 16, 8791-8815, 2016.

Viezee, W., Johnson, W. B., and Singh, H. B.: Stratospheric Ozone in the Lower Troposphere - II. Assessment of Downward Flux and Ground-Level Impact, Atmos. Environ., 17, 1979-1993, 1983.

Vautard, R., Szopa, S., Beekmann, M., Menut, L., Hauglustaine, D. A., Rouil, L., and Roemer, M.: Are decadal anthropogenic emission reductions in Europe consistent with surface ozone observations? Geophys. Res. Lett., 33, L13810, doi:10.1029/2006GL026080, 4 pp., 2006.

Volz, A., and Kley, D.: Evaluation of the Montsouris series of ozone measurements made in the nineteenth century, Nature, 332, 240-242, 1988.

Vogel, B., Pan, L. L., Konopka, P., Günther, G., Müller, R., Hall, W., Campos, T., Pollack, I., Weinheimer, A., Wei, J., Atlas, E. L., and Bowman, K. P.: Transport Pathways and signatures of mixing in the extratropical tropopause region derived from Lagrangian model simulations, J. Geophys. Res., 116, D05306, doi: 10.1029/2010JD014876, 16 pp., 2011.

30 Vogelmann, H. and Trickl, T.: Wide-Range Sounding of Free-Tropospheric Water Vapor with a DifferentialAbsorption Lidar (DIAL) at a High-Altitude Station, Appl. Opt., 47, 2116-2132, 2008.

Vogelmann, H., Sussmann, R., Trickl, T., and Borsdorff, T.: Intercomparison of atmospheric water vapor soundings from the differential absorption lidar (DIAL) and the solar FTIR system on Mt. Zugspitze, Atmos. Meas. Technol., 4, 835-841, 2011.

35 Vogelmann, H., Sussmann, R., Trickl, T., and Reichardt, A.: Spatiotemporal variability of water vapor investigated using lidar and FTIR vertical soundings above the Zugspitze, Atmos. Chem. Phys., 14, 3135-3148, 2015. 
Atmos. Chem. Phys. Discuss., https://doi.org/10.5194/acp-2017-1192

Manuscript under review for journal Atmos. Chem. Phys.

Discussion started: 29 January 2018

(c) Author(s) 2018. CC BY 4.0 License.

Wandinger, U., Freudenthaler, V., Baars, H., Amodeo, A., Engelmann, R., Mattis, I, Groß, S., Pappalardo, G., Giunta, A., D’Amico, G., Chaikovsky, A. Ossipenko, F., Slesar, A., Nicolae, D., Belegante, L., Talianu, C., Serikov, I., Linné, H., Jansen, F., Apituley, A., Wilson, K., de Graaf, M., Trickl, T., Giehl, H., Adam, M., Comeron, A.; Muñoz-Porcar, C., Rocadenbosch, F., Sicard, M., Tomás, S., Lange, D., Kumar, D., Pujadas, M., Molero, F., Fernandez, A. J., Alados Arboledas, L., Bravo-Aranda, J. A., Navas-Guzmán, F., Guerrero-Rascado, J. L., Granados-Munoz, M. J., Preißler, J., Wagner, F., Gausa, M., Grigorov, I., Stoyanov, D., Iarlori, M., Rizi, V., Spinelli, N., Boselli, A., Wang, X., Lo Feudo, T., Perrone, M. R., De Tomasi, F., and Burlizzi, P.: EARLINET instrument intercomparison campaigns: Overview on strategy and results, Atmos. Meas. Tech. 9, 1001-1023, 2016.

10 Wernli, H. and Davies, H. C.: A Lagrangian-based analysis of extratropical cyclones. I. The method and some applications, Q. J. R. Meteorol. Soc., 123, 467-489, 1997a.

Wernli, H.: A Lagrangian-based analysis of extratropical cyclones. II: A detailed case study, Q. J. R. Meteorol. Soc., 123, 1677-1706, 1997b.

Wild, O.: Modelling the global tropospheric ozone budget: exploring the variability in current models, Atmos. Chem. Phys., 7, 2643-2660, 2007.

Young, P. J., Archibald A. T., Bowman, K. W., Lamarque, J.-F., Naik, V., Stevenson, D. S., Tilmes, S., Voulgarakis, A., Wild, O., Bergmann, D., Cameron-Smith, P., Cionni, I., Collins, W. J., Dalsøren, S. B., Doherty, R. M., Eyring, V., Faluvegi, G., Horowitz, L.W., Josse, B., Leen, Y. H., MacKenzie, I. A., Nagashima, T., Plummer, D. A., Righil, M., Rumbold, S. T., Skeie, R. B., Shindell, D. T., Strode, S. A., Sudo, K., Szopa, S., and Zeng, G..: Pre-industrial to end 21st century projections of tropospheric ozone from the Atmospheric Chemistry and Climate Model Intercomparison Project (ACCMIP), Atmos. Chem. Phys., 13, 2063-2090, 2013.

Zanis, P., Gerasopoulos, E., Priller, A., Schnabel, C., Stohl, A., Zerefos, C. S., Gäggeler, H. W., Tobler, L., Kubik, P. W., Kanter, H. J., Scheel, H. E., Luterbacher, J., and Berger, M.: An estimate of the impact of Stratosphere-to-Troposphere Transport (STT) on the lower free tropospheric ozone over the Alps using ${ }^{10} \mathrm{Be}$ and ${ }^{7}$ Be measurements, J. Geophys. Res., 108, doi: 10.1029/2002JD002604, 2003a.

Zanis, P., Trickl, T., Stohl, A., Wernli, H., Cooper, O., Zerefos, C., Gaeggeler, H., Priller, A., Schnabel, C., Scheel, H. E., Kanter, H. J., Tobler, L., Kubik, P. W., Cristofanelli, P., Forster, C., James, P., Gerasopoulos, E., Delcloo, A., Papayannis, A., and Claude, H.: Forecast, observation and modelling of a deep stratospheric intrusion event over Europe, Atmos. Chem. Phys., 3, 763-777, $2003 \mathrm{~b}$. 
Atmos. Chem. Phys. Discuss., https://doi.org/10.5194/acp-2017-1192

Manuscript under review for journal Atmos. Chem. Phys.

Discussion started: 29 January 2018

(c) Author(s) 2018. CC BY 4.0 License.
Atmospheric

Chemistry

and Physics

Discussions

Table 1. Measurement days (first line for a given year) and number of evaluated measurements for a given month (second line); sumd means the the number of measurement days, summ the number of evaluated measurements

\begin{tabular}{|c|c|c|c|c|c|c|c|c|c|c|c|c|c|}
\hline \multirow{3}{*}{5} & Year & Jan & Feb & Mar & Apr & May & June & July & Aug & Sep & Oct & Nov & Dec \\
\hline & 2007 & & & & $\begin{array}{r}8 \\
21\end{array}$ & $\begin{array}{r}8 \\
50\end{array}$ & $\begin{array}{r}6 \\
15\end{array}$ & & & $\begin{array}{l}2 \\
7\end{array}$ & $\begin{array}{r}8 \\
28\end{array}$ & $\begin{array}{r}7 \\
22\end{array}$ & $\begin{array}{r}7 \\
16\end{array}$ \\
\hline & 2008 & & $\begin{array}{r}4 \\
14\end{array}$ & $\begin{array}{r}3 \\
25\end{array}$ & $\begin{array}{r}7 \\
28\end{array}$ & $\begin{array}{l}11 \\
41\end{array}$ & $\begin{array}{l}5 \\
9\end{array}$ & $\begin{array}{l}1 \\
5\end{array}$ & $\begin{array}{r}7 \\
24\end{array}$ & $\begin{array}{r}2 \\
11\end{array}$ & $\begin{array}{r}9 \\
28\end{array}$ & $\begin{array}{l}12 \\
67\end{array}$ & $\begin{array}{r}5 \\
45\end{array}$ \\
\hline \multirow[t]{3}{*}{10} & 2009 & $\begin{array}{r}8 \\
45\end{array}$ & $\begin{array}{l}10 \\
63\end{array}$ & $\begin{array}{l}1 \\
1\end{array}$ & $\begin{array}{r}9 \\
46\end{array}$ & $\begin{array}{l}1 \\
2\end{array}$ & $\begin{array}{r}4 \\
12\end{array}$ & $\begin{array}{r}9 \\
49\end{array}$ & $\begin{array}{l}11 \\
56\end{array}$ & $\begin{array}{r}3 \\
19\end{array}$ & $\begin{array}{r}7 \\
51\end{array}$ & & \\
\hline & 2011 & & & & & & & $\begin{array}{r}4 \\
12\end{array}$ & $\begin{array}{l}1 \\
6\end{array}$ & $\begin{array}{r}5 \\
16\end{array}$ & $\begin{array}{r}6 \\
16\end{array}$ & $\begin{array}{r}6 \\
21\end{array}$ & $\begin{array}{l}1 \\
3\end{array}$ \\
\hline & 2012 & & & & & & & & & & & $\begin{array}{l}1 \\
6\end{array}$ & $\begin{array}{l}2 \\
4\end{array}$ \\
\hline \multirow[t]{2}{*}{15} & 2013 & $\begin{array}{l}2 \\
3\end{array}$ & $\begin{array}{r}6 \\
21\end{array}$ & $\begin{array}{l}2 \\
8\end{array}$ & & & $\begin{array}{r}5 \\
20\end{array}$ & $\begin{array}{l}16 \\
52\end{array}$ & $\begin{array}{l}2 \\
9\end{array}$ & $\begin{array}{l}11 \\
42\end{array}$ & $\begin{array}{l}13 \\
60\end{array}$ & $\begin{array}{r}6 \\
21\end{array}$ & $\begin{array}{l}15 \\
70\end{array}$ \\
\hline & 2014 & $\begin{array}{r}9 \\
37\end{array}$ & $\begin{array}{l}16 \\
59\end{array}$ & $\begin{array}{l}20 \\
64\end{array}$ & $\begin{array}{l}10 \\
39\end{array}$ & $\begin{array}{r}8 \\
22\end{array}$ & $\begin{array}{l}18 \\
43\end{array}$ & $\begin{array}{r}9 \\
27\end{array}$ & $\begin{array}{r}8 \\
24\end{array}$ & $\begin{array}{r}9 \\
28\end{array}$ & $\begin{array}{l}14 \\
34\end{array}$ & $\begin{array}{l}13 \\
40\end{array}$ & $\begin{array}{l}12 \\
36\end{array}$ \\
\hline \multirow[t]{2}{*}{20} & 2015 & $\begin{array}{l}13 \\
37\end{array}$ & $\begin{array}{l}16 \\
61\end{array}$ & $\begin{array}{l}12 \\
51\end{array}$ & $\begin{array}{l}18 \\
63\end{array}$ & $\begin{array}{r}7 \\
26\end{array}$ & $\begin{array}{l}17 \\
51\end{array}$ & $\begin{array}{r}4 \\
11\end{array}$ & $\begin{array}{l}16 \\
57\end{array}$ & $\begin{array}{l}11 \\
31\end{array}$ & $\begin{array}{l}12 \\
52\end{array}$ & $\begin{array}{l}11 \\
52\end{array}$ & \\
\hline & 2016 & & & & & $\begin{array}{l}2 \\
4\end{array}$ & $\begin{array}{l}10 \\
54\end{array}$ & $\begin{array}{l}11 \\
45\end{array}$ & & & & & \\
\hline 25 & $\begin{array}{l}\text { Sumd } \\
\text { Summ }\end{array}$ & $\begin{array}{l}33 \\
122\end{array}$ & $\begin{array}{l}51 \\
218\end{array}$ & $\begin{array}{l}38 \\
149\end{array}$ & $\begin{array}{l}52 \\
197\end{array}$ & $\begin{array}{l}37 \\
145\end{array}$ & $\begin{array}{l}65 \\
204\end{array}$ & $\begin{array}{l}54 \\
201\end{array}$ & $\begin{array}{l}45 \\
176\end{array}$ & $\begin{array}{l}43 \\
154\end{array}$ & $\begin{array}{l}69 \\
269\end{array}$ & $\begin{array}{l}56 \\
229\end{array}$ & $\begin{array}{l}42 \\
174\end{array}$ \\
\hline & $\begin{array}{l}\text { Total } \\
\text { Total }\end{array}$ & $\begin{array}{l}\text { numb } \\
\text { numl }\end{array}$ & $\begin{array}{l}\text { of } m \\
\text { of } e\end{array}$ & $\begin{array}{l}\text { sure } \\
\text { uate }\end{array}$ & $\begin{array}{l}\text { nents } \\
\text { meas }\end{array}$ & $\begin{array}{l}\text { ays: } \\
\text { remen }\end{array}$ & & $\begin{array}{r}585 \\
2238\end{array}$ & & & & & \\
\hline
\end{tabular}


Atmos. Chem. Phys. Discuss., https://doi.org/10.5194/acp-2017-1192

Manuscript under review for journal Atmos. Chem. Phys.

Discussion started: 29 January 2018

(C) Author(s) 2018. CC BY 4.0 License.

\section{Figures:}

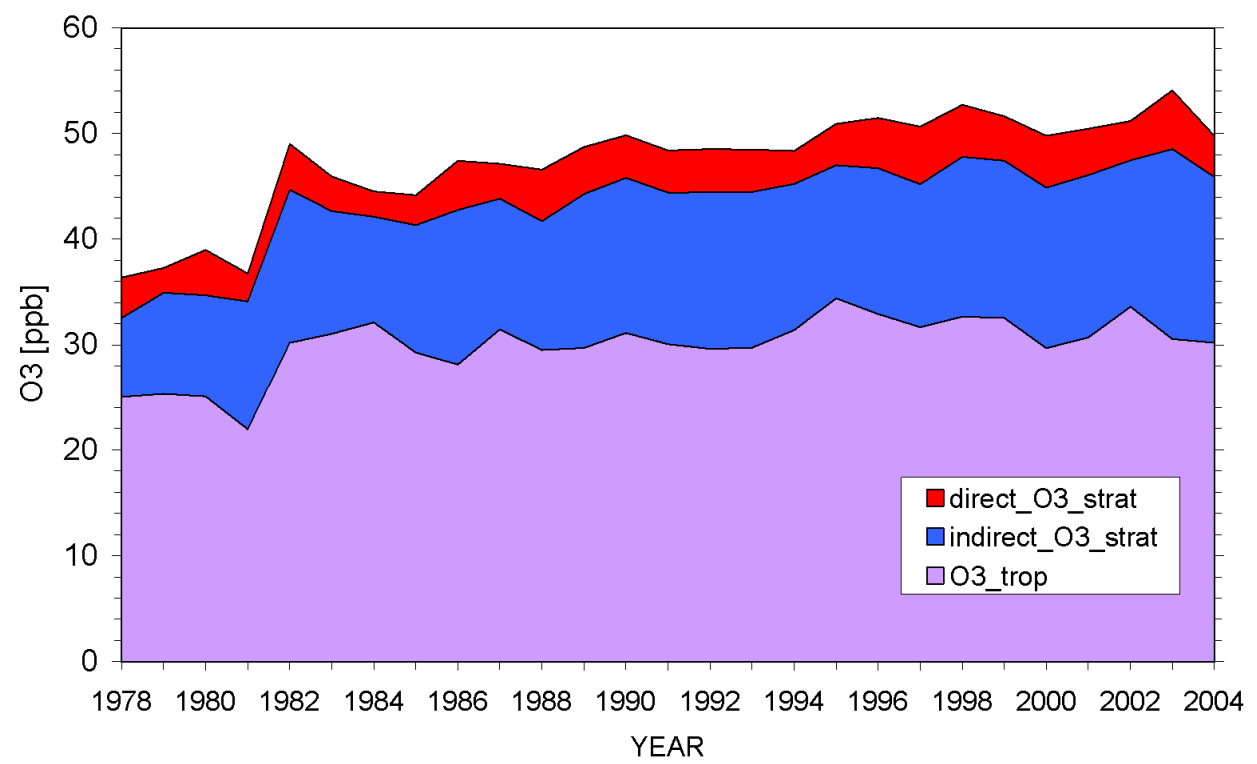

Fig. 1. Annual mean ozone mixing ratios for the Zugspitze summit from 1978 to 2003, together with preliminary estimates of the directly detected stratospheric component (red) and of the indirect component (blue) obtained

5 from ${ }^{7} \mathrm{Be}$ measurements: The stratospheric influence remarkably grew during that period. As a consequence 1981 the positive ozone trend disappears after subtracting the evaluated stratospheric fraction of ozone. The figure is taken from the ATMOFAST final report (2005; Fig. 2.40 on p. 67). 
Atmos. Chem. Phys. Discuss., https://doi.org/10.5194/acp-2017-1192

Manuscript under review for journal Atmos. Chem. Phys.

Discussion started: 29 January 2018

(c) Author(s) 2018. CC BY 4.0 License.
Atmospheric

Chemistry

and Physics

Discussions

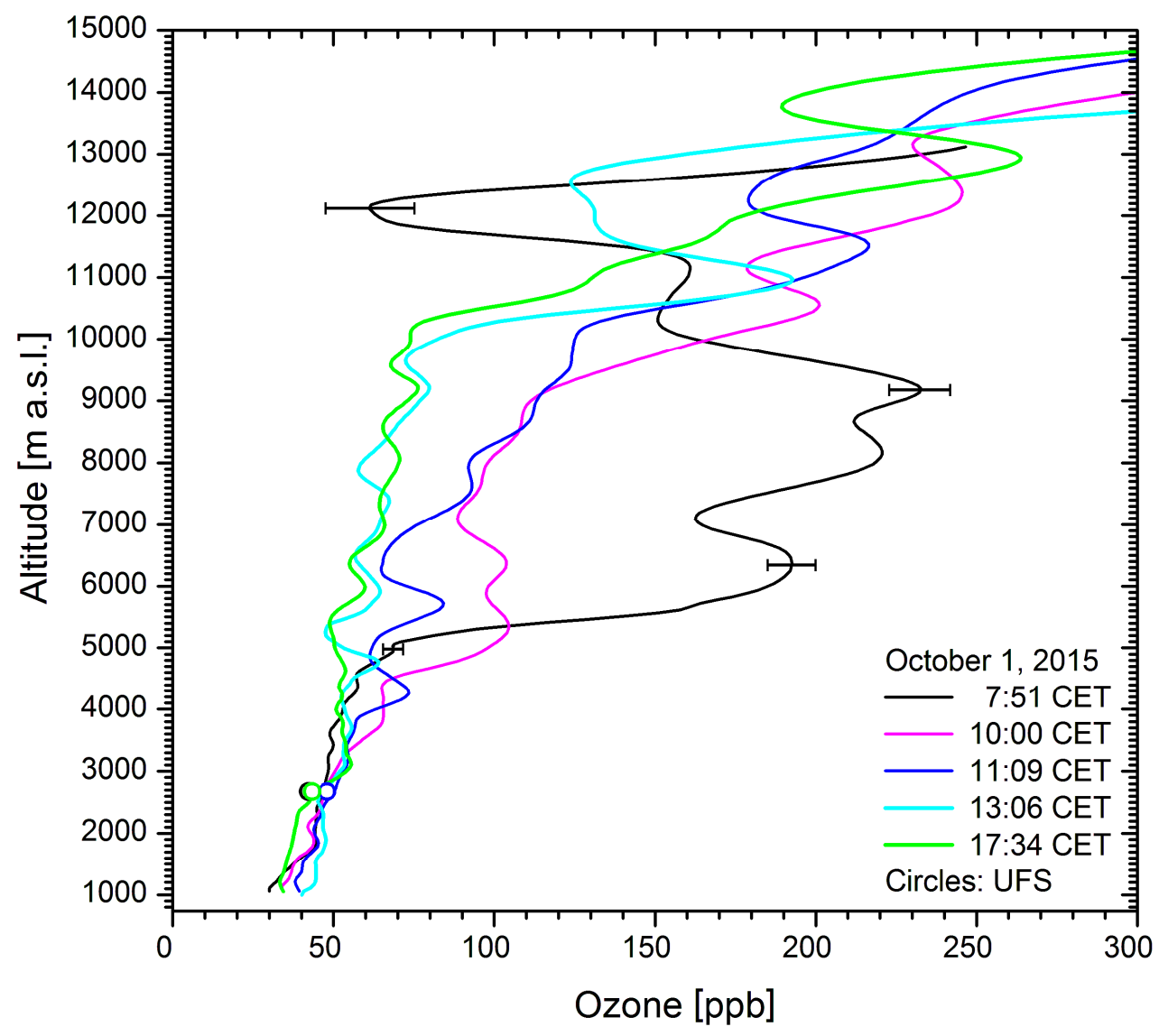

Fig. 2. Vertical ozone profiles from the lidar measurements on 1 October 2015; 235 ppb is the highest mixing ratio ever measured with the IFU DIAL since the beginning of the measurements in 1991. The distribution changes dramatically within about ten hours. The Munich thermal tropopause level was $10454 \mathrm{~m}(0 \mathrm{UTC}=1$ CET) and $11903 \mathrm{~m}$ (12 UTC). The minimum sonde RH was $2 \%$ (0 UTC) and $1 \%$ (cut-off level, 12 UTC). . The in-situ data (1-h averages) of UFS $(2670 \mathrm{~m})$ are marked with circles coded in the same colours as the lidar measurements next to the same time. 
Atmos. Chem. Phys. Discuss., https://doi.org/10.5194/acp-2017-1192

Manuscript under review for journal Atmos. Chem. Phys.

Discussion started: 29 January 2018

(c) Author(s) 2018. CC BY 4.0 License.
Atmospheric

Chemistry

and Physics

Discussions

(c) (i)

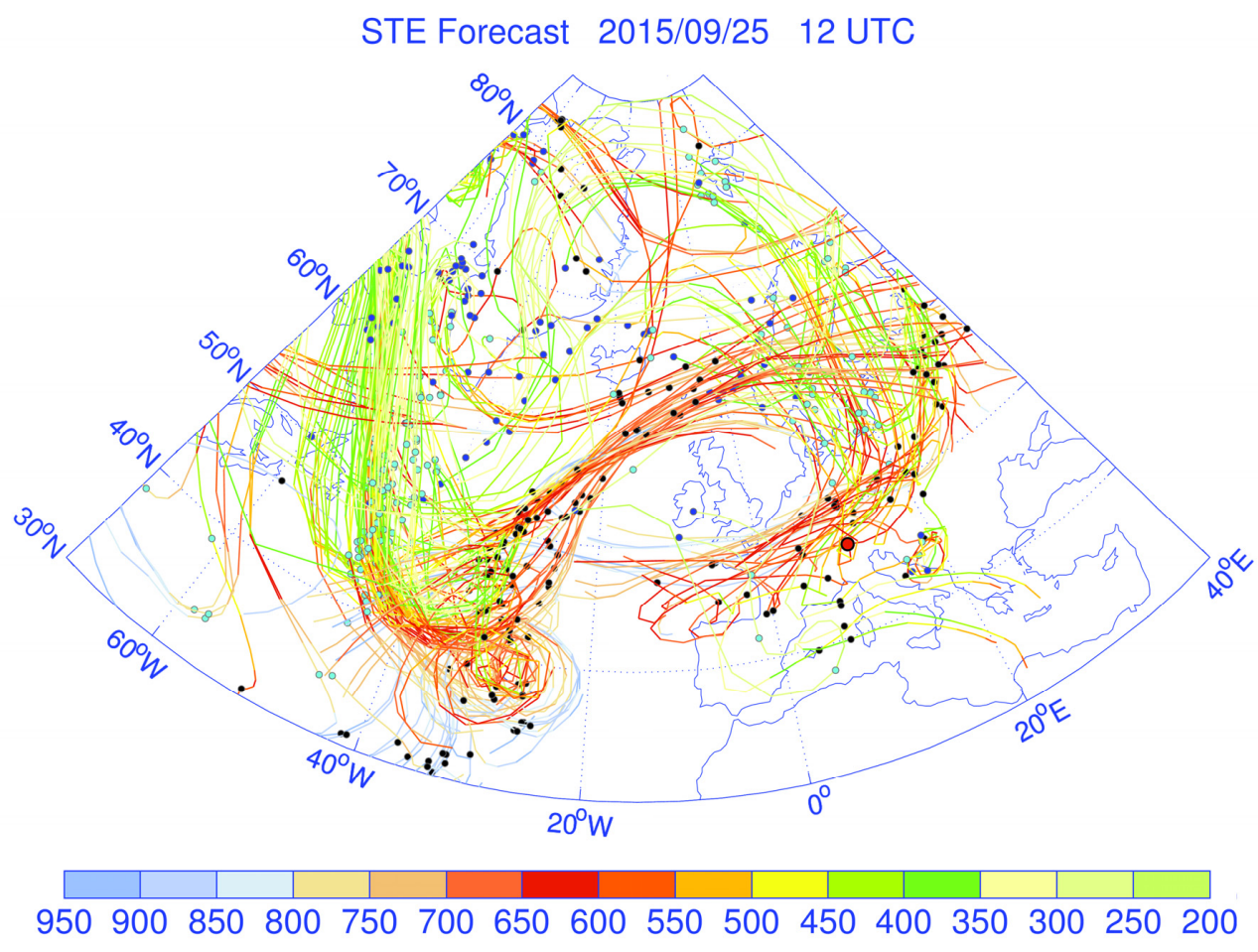

Fig. 3. Recalculation of the LAGRANTO forward trajectories based on ERA Interim meteorological data: The length of the trajectories is five days. Only less than $1 \%$ of the trajectories are displayed for clearness. The pressure level is colour coded in mbar as shown at the bottom. The start time $t_{0}$ is 25 September 2017, 12 UTC (13 CET) marked by dark blue dots. The times $t_{0}+2 \mathrm{~d}$ and $\mathrm{t}_{0}+4 \mathrm{~d}$ are marked with bright blue and black dots, respectively. 
Atmos. Chem. Phys. Discuss., https://doi.org/10.5194/acp-2017-1192

Manuscript under review for journal Atmos. Chem. Phys.

Discussion started: 29 January 2018

(C) Author(s) 2018. CC BY 4.0 License.
Atmospheric

Chemistry

and Physics

Discussions

(c) (1)

December 30, 2013

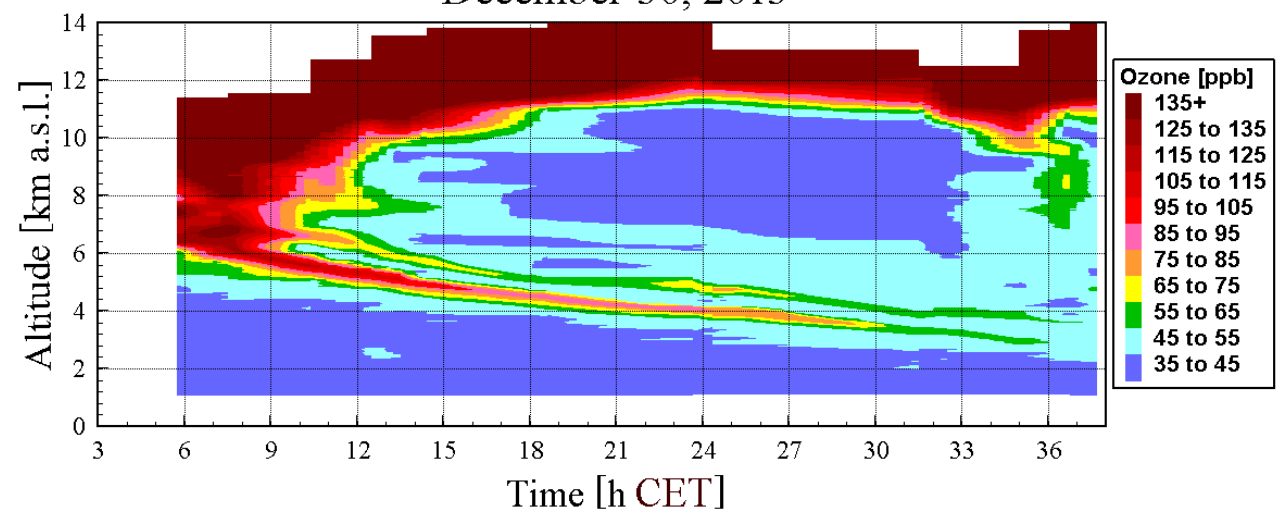

Fig. 4. DIAL ozone soundings on the final two days of 2013 showing two narrow layers descending parallel to below $4 \mathrm{~km}$ a.s.1. 
Atmos. Chem. Phys. Discuss., https://doi.org/10.5194/acp-2017-1192

Manuscript under review for journal Atmos. Chem. Phys.

Discussion started: 29 January 2018

(c) Author(s) 2018. CC BY 4.0 License.
Atmospheric

Chemistry

and Physics

Discussions

(c) (i)
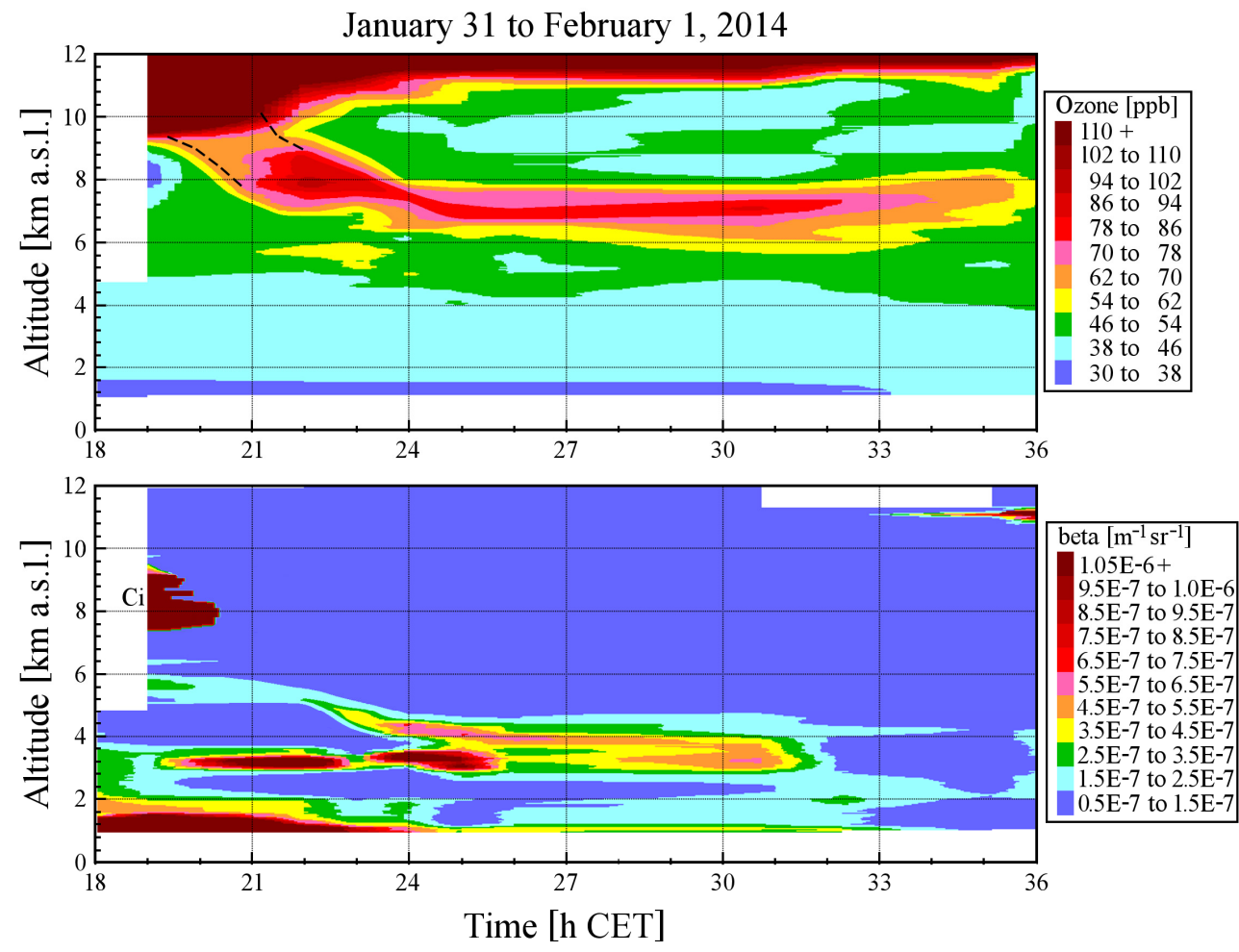

Fig. 5. Time series of ozone (upper panel) and the 313-nm aerosol backscatter coefficient (lower panel) on 31 January and 1 February 2014: Both a stratospheric intrusion layer (6.5-9 km) and a weak to moderate Saharan dust event 2.5-6 km are seen. Due to a 3-h data gap between 19 and 22 CET the colour coding during this period

5 is highly uncertain. The intrusion could also have formed a full tropopause fold as indicated by the dashed black lines. 
Atmos. Chem. Phys. Discuss., https://doi.org/10.5194/acp-2017-1192

Manuscript under review for journal Atmos. Chem. Phys.

Discussion started: 29 January 2018

(c) Author(s) 2018. CC BY 4.0 License.
Atmospheric

Chemistry

and Physics

Discussions

(c) (i)

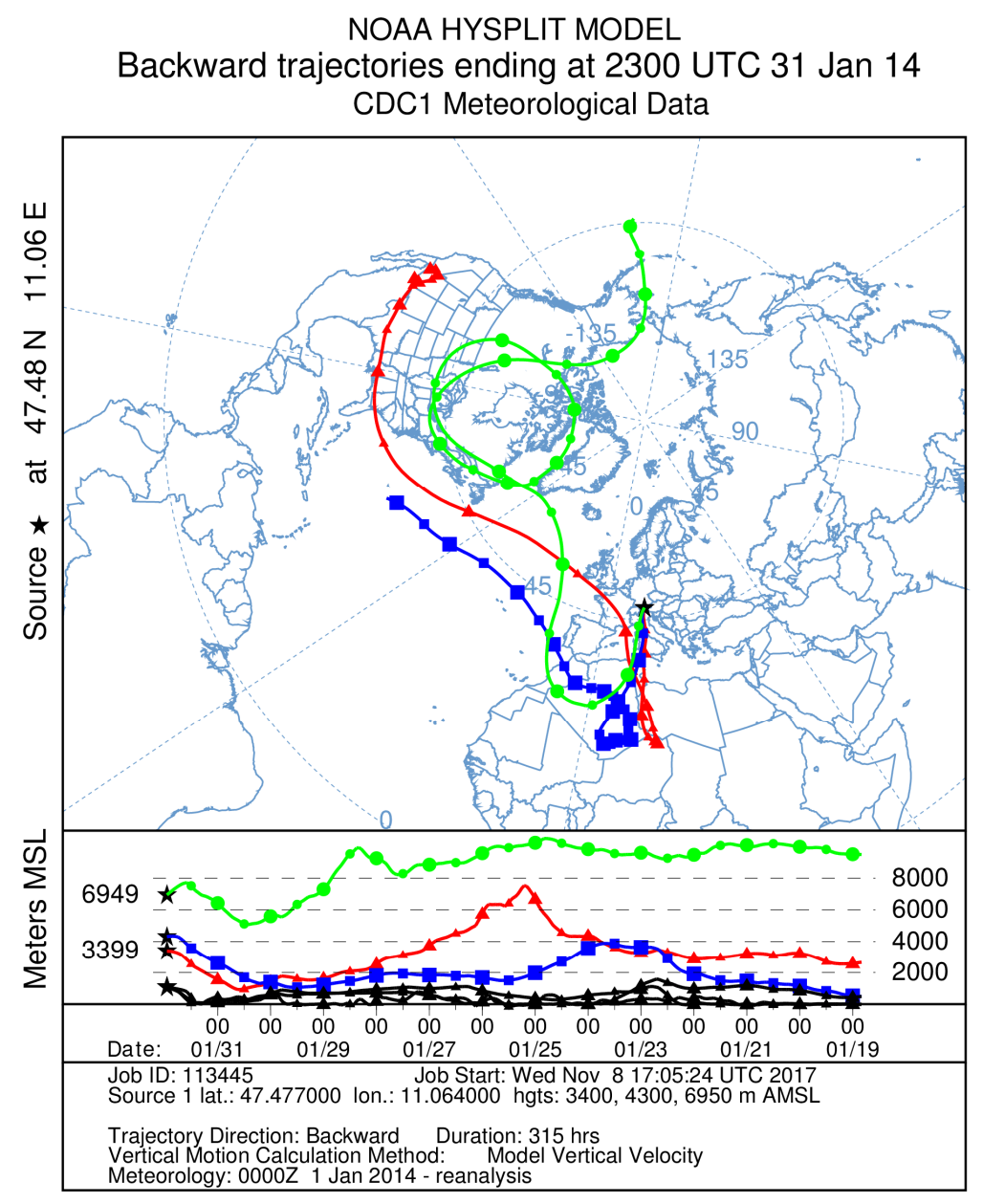

Fig. 6. HYSPLIT 315-h backward trajectories starting above Garmisch-Partenkirchen on 1 February 2014 at 0:00 CET within the two aerosol layers in Fig. 5 (lower panel) between 3 and $4.5 \mathrm{~km}$ as well as in the stratospheric intrusion between 6 and $9 \mathrm{~km}$ (upper panel in Fig. 5); the black curves at the bottom of the vertical cross section mark the ground levels for each trajectory. 
Atmos. Chem. Phys. Discuss., https://doi.org/10.5194/acp-2017-1192

Manuscript under review for journal Atmos. Chem. Phys.

Discussion started: 29 January 2018

(c) Author(s) 2018. CC BY 4.0 License.

(c) (i)
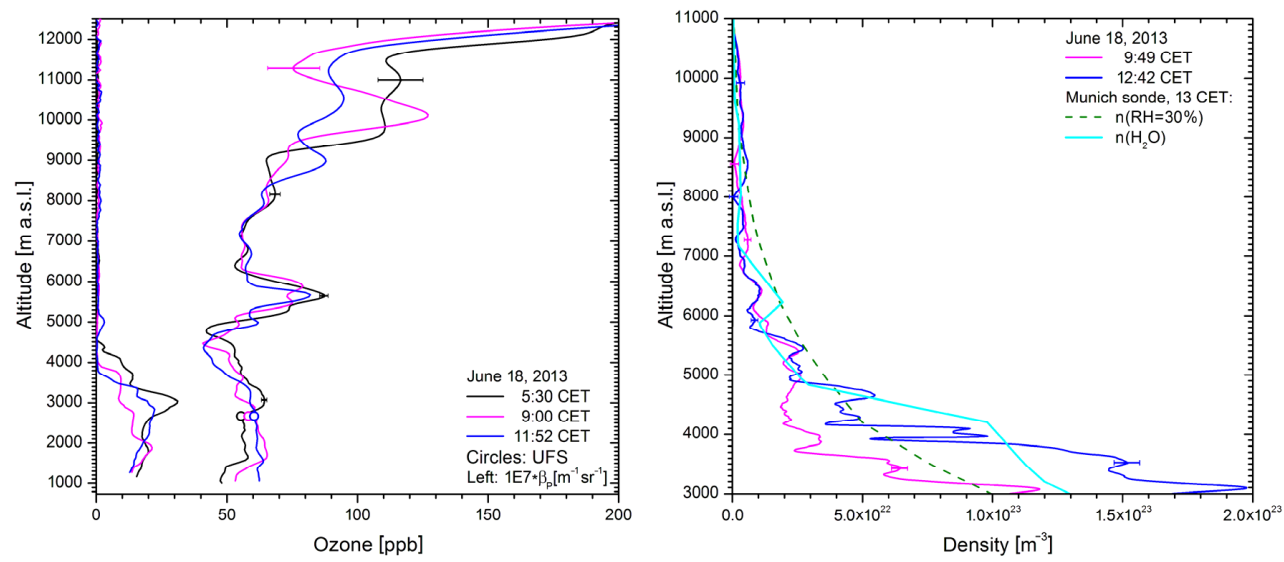

Fig. 7. Profiles of ozone, the aerosol backscatter coefficient (left panel) and the water-vapour number density $n$ (right panel) from DIAL measurements at IFU and UFS on 18 June 2013 during a Saharan dust event; for comparison the densities for $\mathrm{RH}=30 \%$ and the measured $\mathrm{RH}$ by the Munich radiosonde are shown. The 5 stratospheric intrusion peak at around $5.7 \mathrm{~km}$ corresponds to 8-12\% RH because of long-range descent (Fig. 8). Please, note that the times specified for the UFS DIAL are the end times of the respective measurement (lasting about $16 \mathrm{~min})$. The in-situ data of UFS $(2670 \mathrm{~m})$ are marked with circles coded in the same colours as the lidar measurements next to the same time and confirm the values from the lidar measurements within 1-2 ppb. 
Atmos. Chem. Phys. Discuss., https://doi.org/10.5194/acp-2017-1192

Manuscript under review for journal Atmos. Chem. Phys.

Discussion started: 29 January 2018

(c) Author(s) 2018. CC BY 4.0 License.
Atmospheric

Chemistry

and Physics

Discussions

(c) $\underset{\mathrm{BY}}{(i)}$

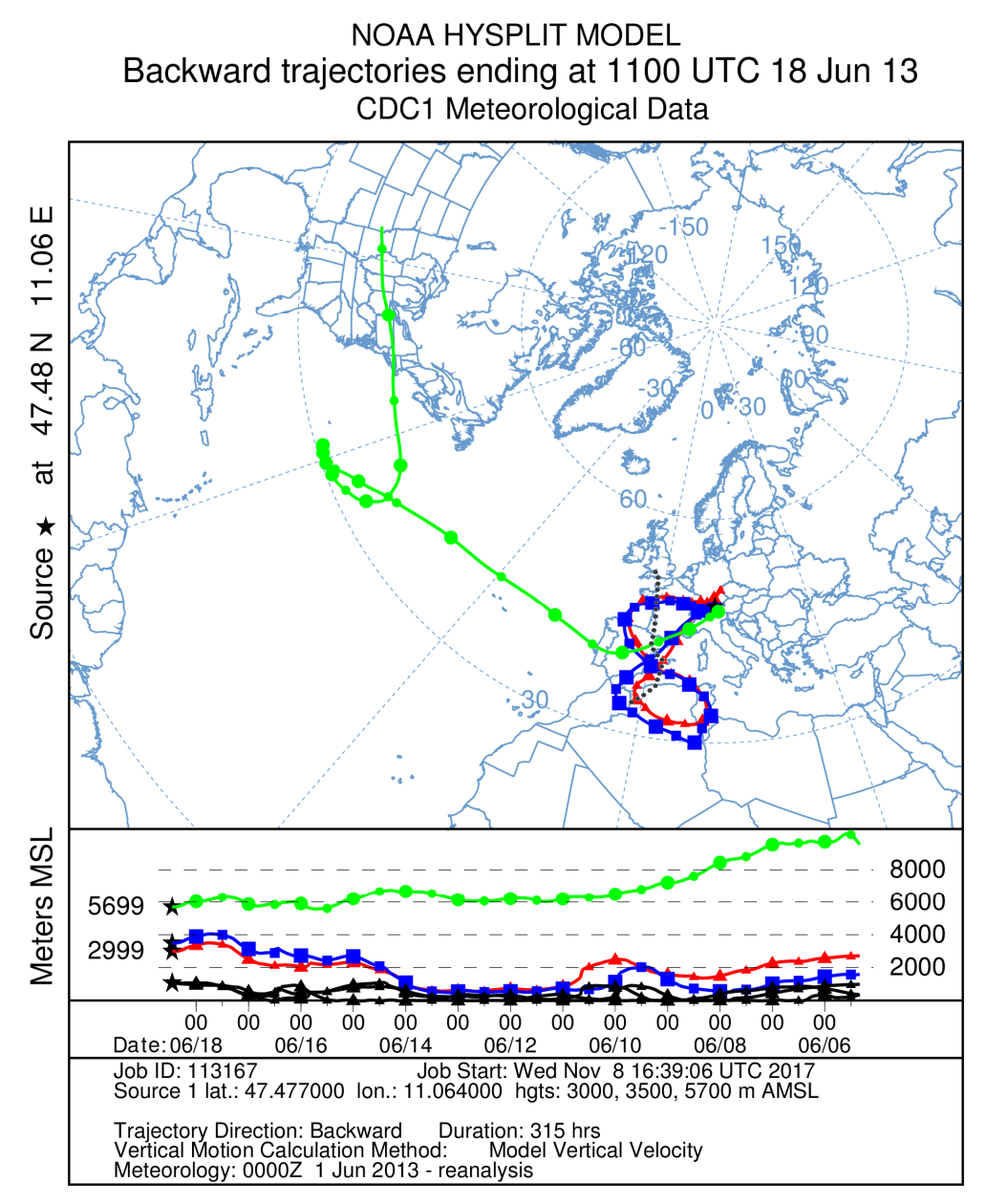

Fig. 8. HYSPLIT 315-h backward trajectories starting above Garmisch-Partenkirchen on 18 June 2013 at 11 UTC (12 CET) within the Saharan dust layer as well as in stratospheric intrusion at $5.7 \mathrm{~km}$ (see Fig. 5); the black curves at the bottom of the vertical cross section mark the ground levels for each trajectory. The dotted black line 5 indicates the arriving cold front on 18 June 2013, 13 CET. 
Atmos. Chem. Phys. Discuss., https://doi.org/10.5194/acp-2017-1192

Manuscript under review for journal Atmos. Chem. Phys.

Discussion started: 29 January 2018

(c) Author(s) 2018. CC BY 4.0 License.

(c) (i)
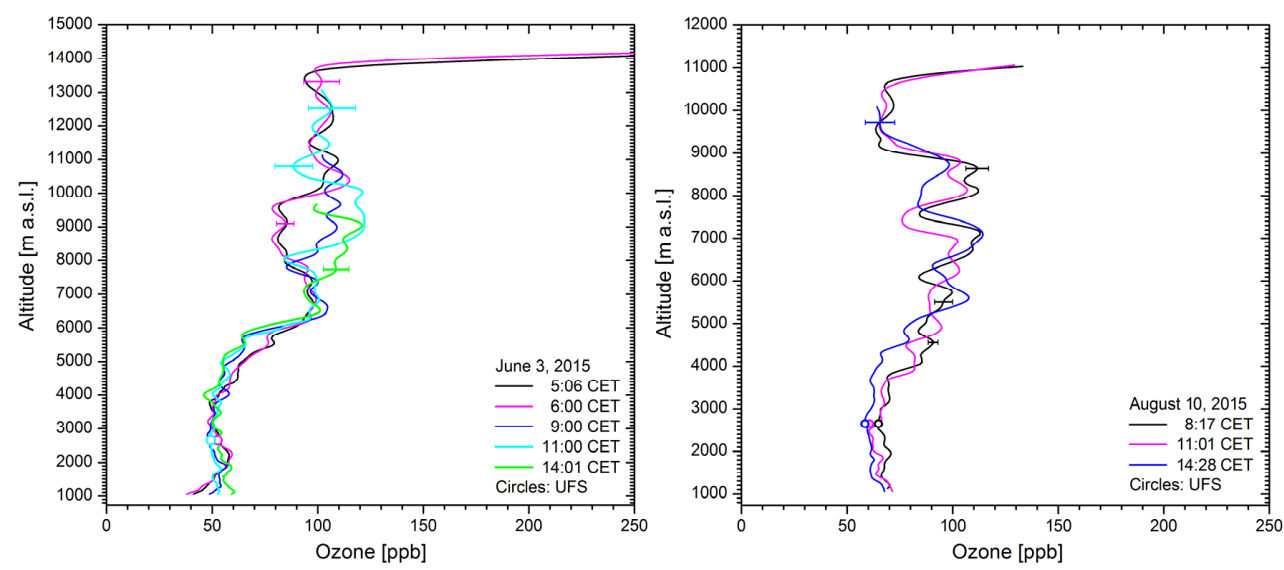

Fig. 9. Ozone profiles from 3 June 2015 (left panel) and 10 August 2015 (right panel) showing very high ozone above $5 \mathrm{~km}$ and $3.8 \mathrm{~km}$, respectively; the high values are mostly explained by STT. The in-situ data (1-h averages) of UFS $(2670 \mathrm{~m})$ are marked with circles coded in the same colours as the lidar measurements next to

5 the same time and confirm the values from the lidar measurements within 1 to $2 \mathrm{ppb}$. Munich tropopause: 13782 m (3 June, 0 UTC), 13764 m (3 June, 12 UTC), 12471 m (10 August, 0 UTC) and 11029 m (10 August, 12 UTC). 
Atmos. Chem. Phys. Discuss., https://doi.org/10.5194/acp-2017-1192

Manuscript under review for journal Atmos. Chem. Phys.

Discussion started: 29 January 2018

(c) Author(s) 2018. CC BY 4.0 License.
Atmospheric

Chemistry

and Physics

Discussions

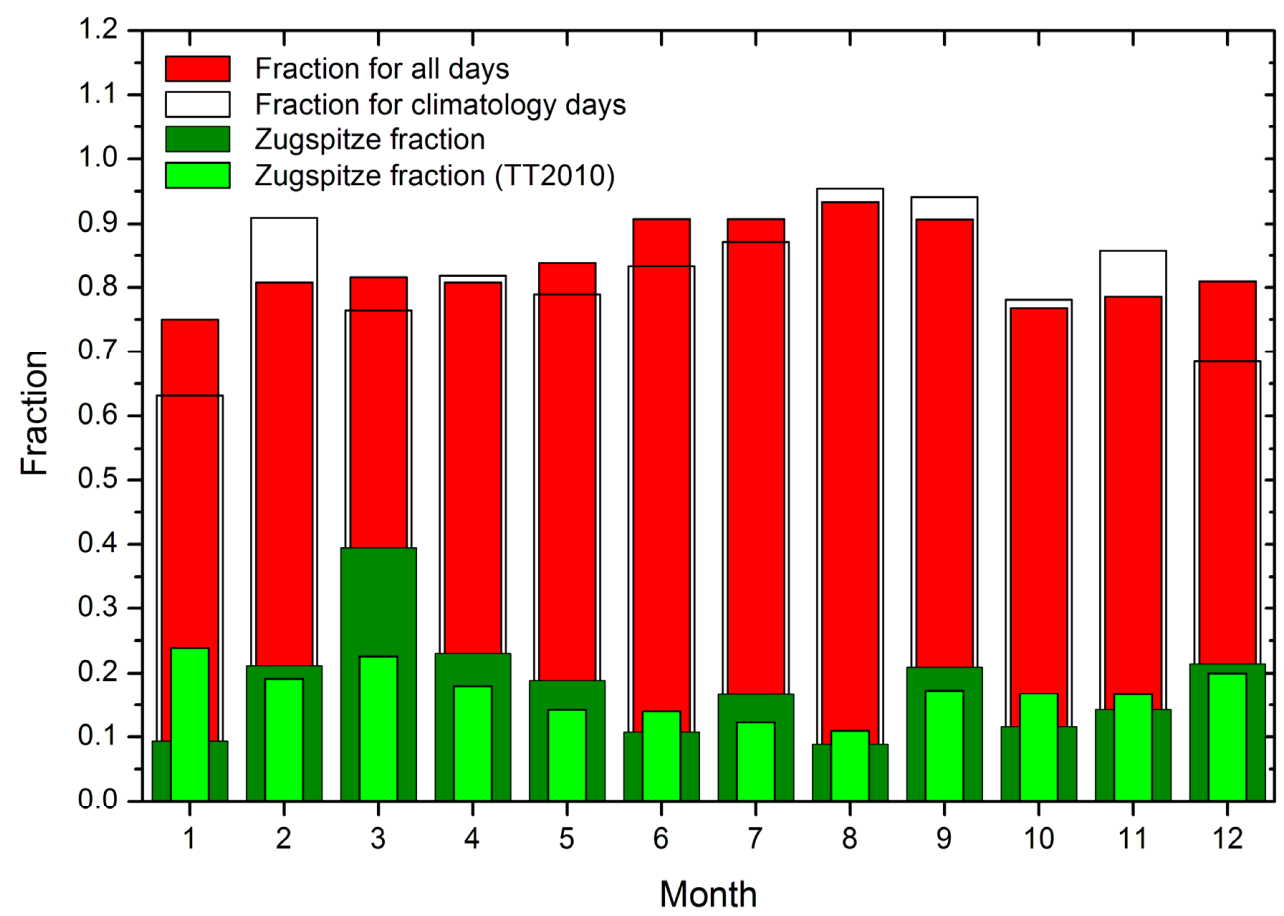

Fig. 10. Fraction of intrusion days in the ozone lidar data averaged for each month between 2007 and 2016 (see text); for comparison, the same analysis is shown for those intrusion days that show stratospheric influence at $2962 \mathrm{~m}$ (Zugspitze), together with the maximum fractions calculated from the data underlying Fig. 12 in (Trickl 5 et al., 2010). 
Atmos. Chem. Phys. Discuss., https://doi.org/10.5194/acp-2017-1192

Manuscript under review for journal Atmos. Chem. Phys.

Discussion started: 29 January 2018

(c) Author(s) 2018. CC BY 4.0 License.

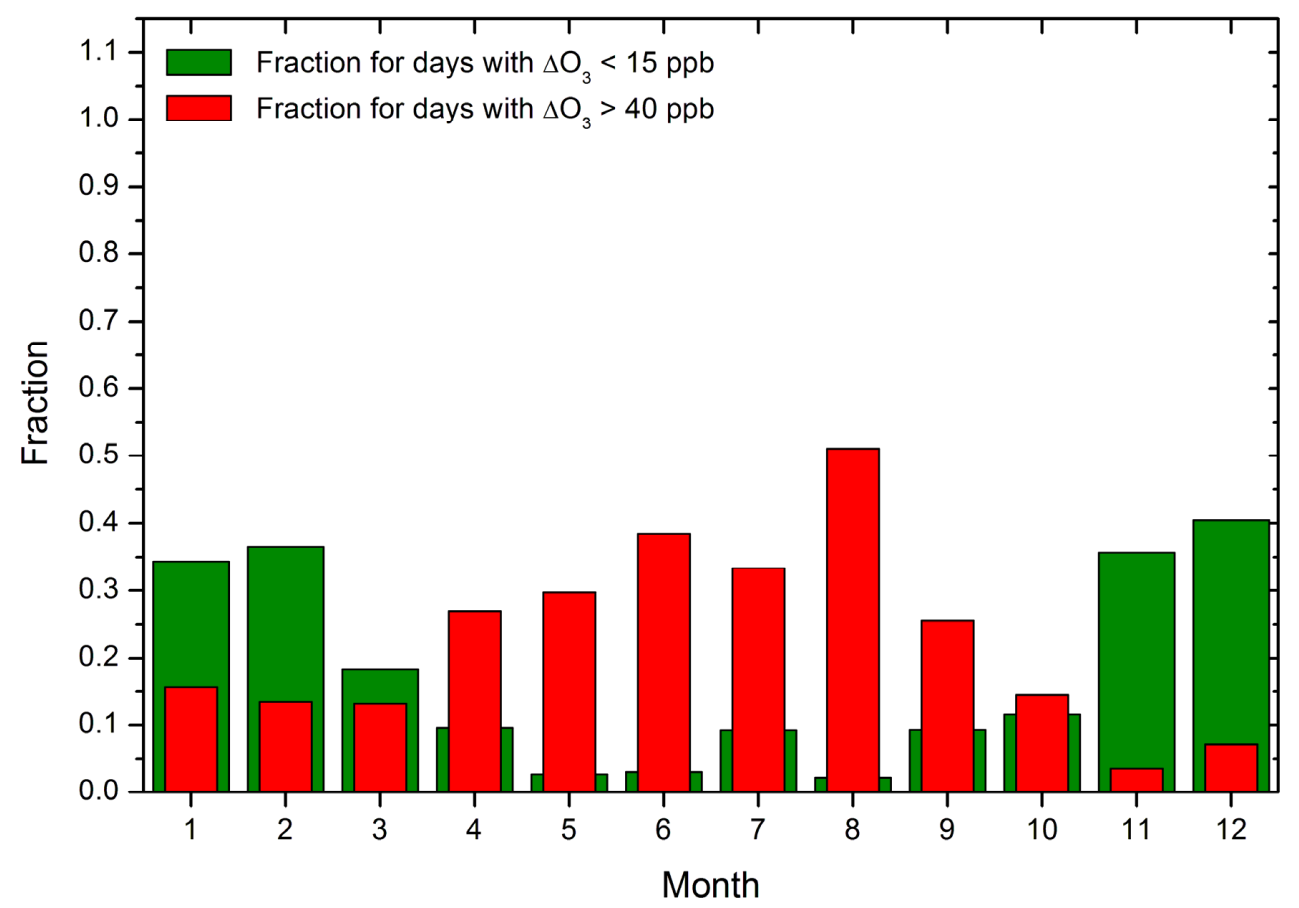

Fig. 11. Fraction of intrusion days in the ozone lidar data with weak and strong peaks averaged for each month between 2007 and 2016 (see text) 
Atmos. Chem. Phys. Discuss., https://doi.org/10.5194/acp-2017-1192

Manuscript under review for journal Atmos. Chem. Phys.

Discussion started: 29 January 2018

(c) Author(s) 2018. CC BY 4.0 License.

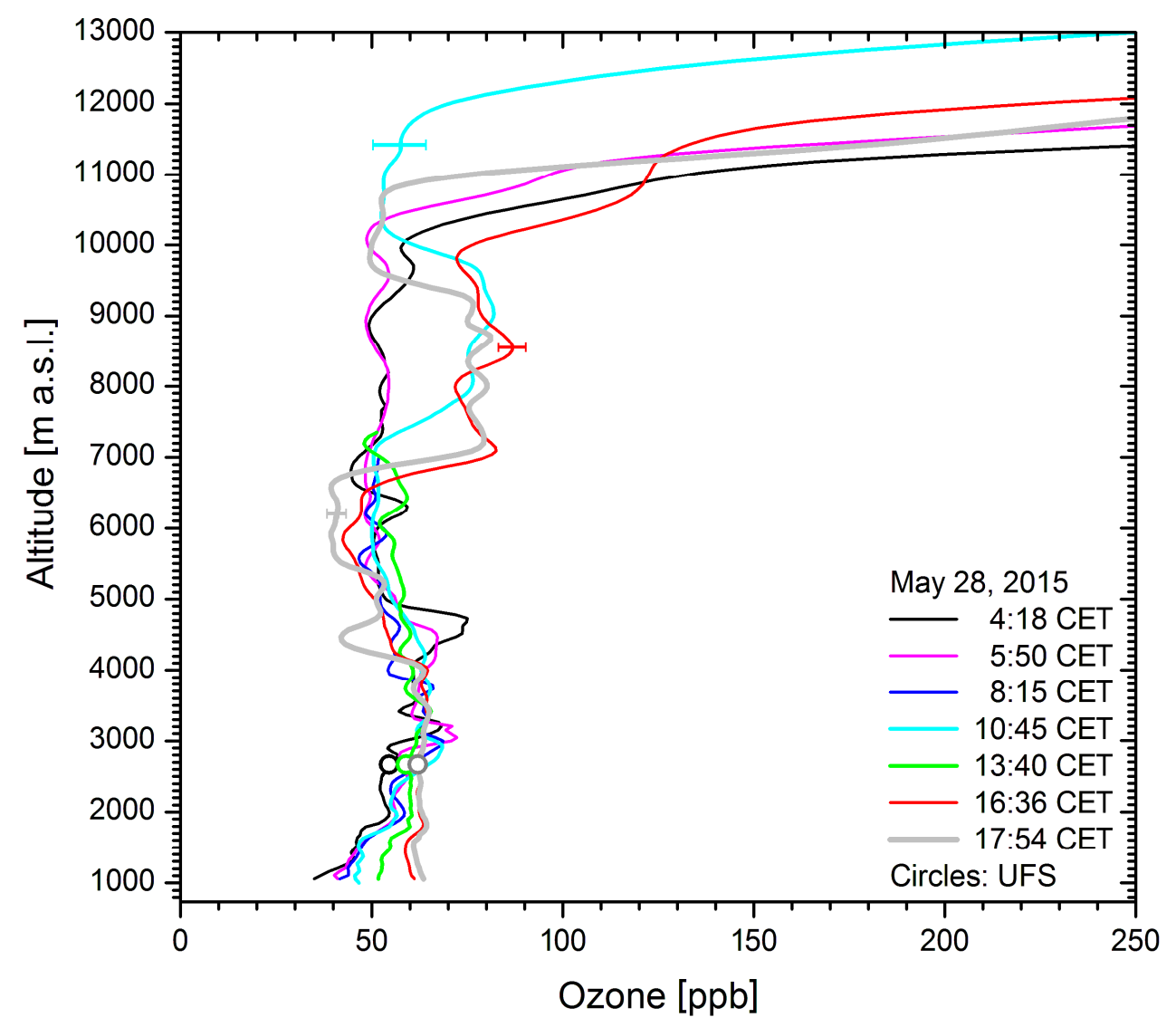

Fig. 12. Profiles of ozone from DIAL measurements at IFU (Garmisch-Partenkirchen) on 28 May 2015; the pronounced diurnal of the vertical distribution is ascribed to a quick change in source regions at different altitudes. Between 7.5 and $9.5 \mathrm{~km}$ about $80 \mathrm{ppb}$ from a high-ozone area in the U.S. east of the Mississippi was observed. Intrusion layers are temporarily seen at about $3.1 \mathrm{~km}, 4.7 \mathrm{~km}$ and $7.1 \mathrm{~km}$. The in-situ data of UFS $(2670 \mathrm{~m})$ are marked with circles coded in the same colours as the lidar measurements next to the same time. The temporary upward shift of the tropopause (bright blue curve) was caused by a humid layer containing a cirrus cloud. 
Atmos. Chem. Phys. Discuss., https://doi.org/10.5194/acp-2017-1192

Manuscript under review for journal Atmos. Chem. Phys.

Discussion started: 29 January 2018

(c) Author(s) 2018. CC BY 4.0 License.
Atmospheric

Chemistry

and Physics

Discussions

(c) (i)

\section{NOAA HYSPLIT MODEL \\ Backward trajectories ending at 1700 UTC 28 May 15 \\ CDC1 Meteorological Data}

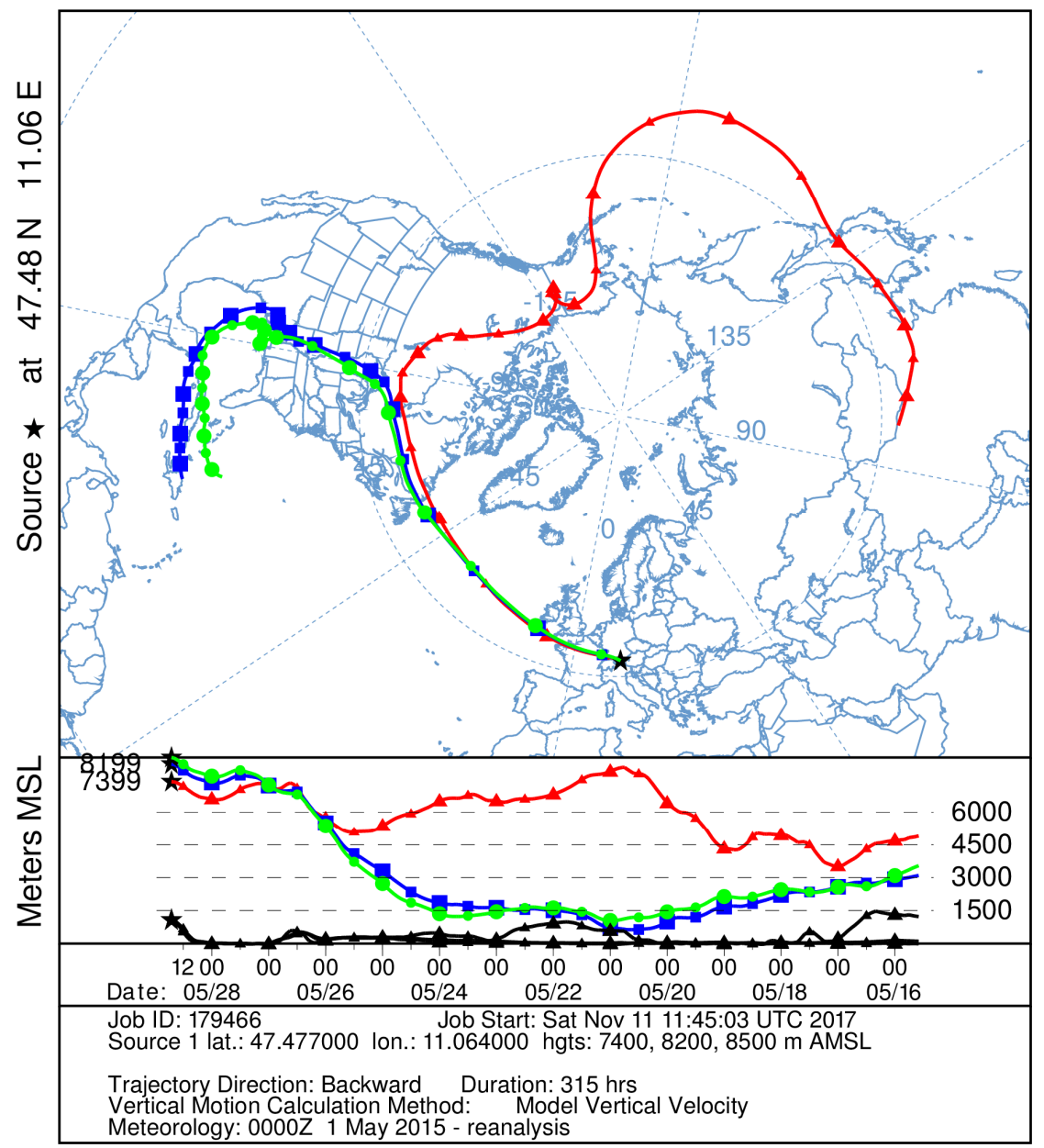

Fig. 13. HYSPLIT 315-h backward trajectories starting above Garmisch-Partenkirchen on 18 June 2013 at 11 UTC (12 CET) within the Saharan dust layer as well as in stratospheric intrusion at $5.7 \mathrm{~km}$ (see Fig. 5); the black curves at the bottom of the vertical cross section mark the ground levels for each trajectory. The dotted black line indicates the cold front on 18 June 2013, 13 CET. 
Atmos. Chem. Phys. Discuss., https://doi.org/10.5194/acp-2017-1192

Manuscript under review for journal Atmos. Chem. Phys.

Discussion started: 29 January 2018

(c) Author(s) 2018. CC BY 4.0 License.
Atmospheric

Chemistry

and Physics

Discussions

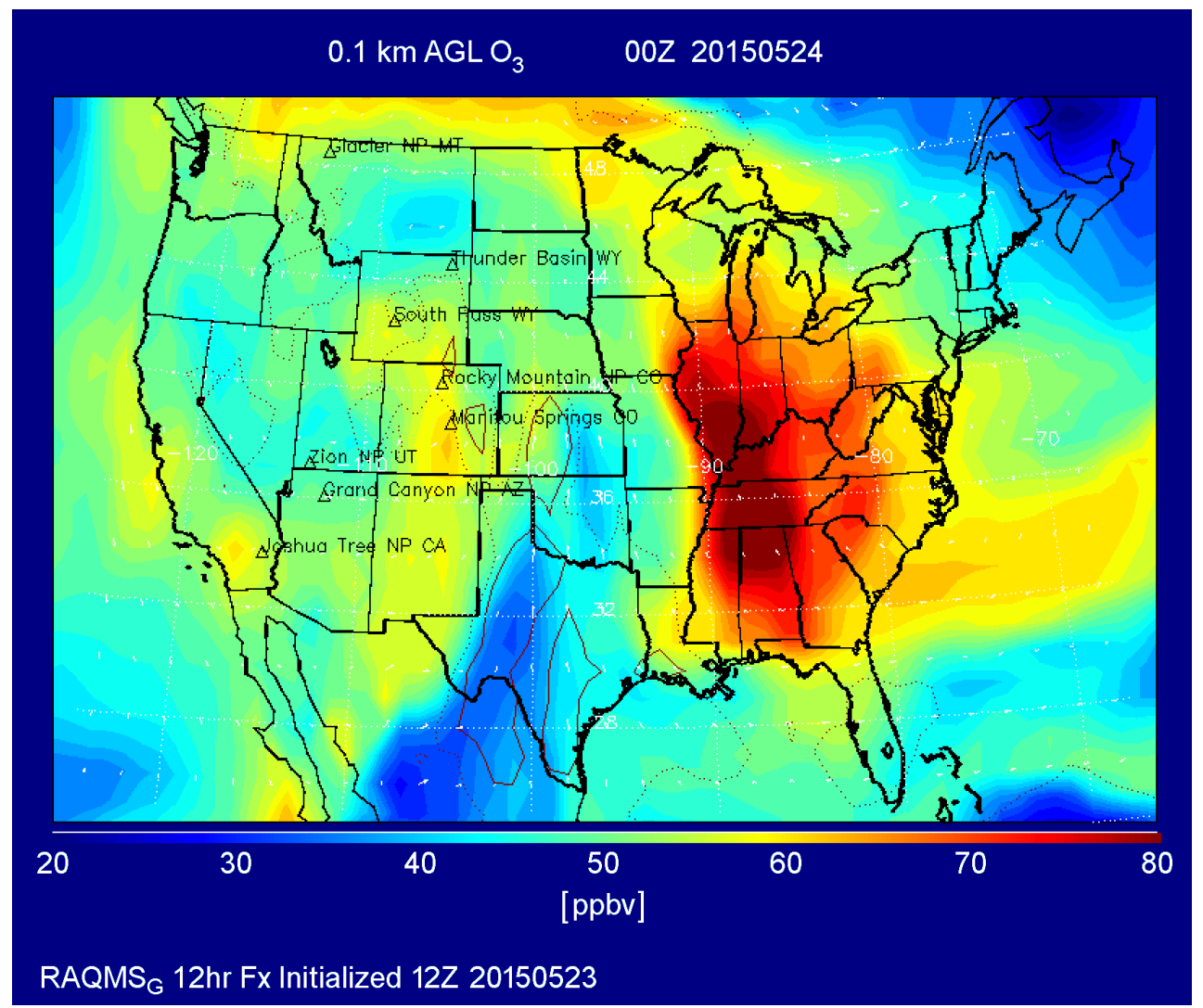

Fig. 14. Ozone over the U.S. on 24 May 2015 showing mixing ratios of more than 80 ppb east of the Mississippi (RAQMS (Real-time Air Quality Modeling System) calculation kindly provided by B. Pierce (NOAA)) 